\title{
Soil compaction impact and modelling. A review
}

\author{
Muhammad Farrakh Nawaz • Guilhem Bourrié • \\ Fabienne Trolard
}

Accepted: 1 December 2011 / Published online: 31 January 2012

(C) The Author(s) 2012. This article is published with open access at Springerlink.com

\begin{abstract}
Compaction of agricultural soils is a concern for many agricultural soil scientists and farmers since soil compaction, due to heavy field traffic, has resulted in yield reduction of most agronomic crops throughout the world. Soil compaction is a physical form of soil degradation that alters soil structure, limits water and air infiltration, and reduces root penetration in the soil. Consequences of soil compaction are still underestimated. A complete understanding of processes involved in soil compaction is necessary to meet the future global challenge of food security. We review here the advances in understanding, quantification, and prediction of the effects of soil compaction. We found the following major points: (1) When a soil is exposed to a vehicular traffic load, soil water contents, soil texture and structure, and soil organic matter are the three main factors which determine the degree of compactness in that soil. (2) Soil compaction has direct effects on soil physical properties such as bulk density, strength, and porosity; therefore, these parameters can be used to quantify the soil compactness. (3) Modified soil physical properties due to soil compaction can alter elements mobility and change nitrogen and carbon cycles in favour of more emissions of greenhouse gases under wet conditions. (4) Severe soil compaction induces root deformation, stunted shoot growth, late germination, low germination rate, and high mortality rate. (5) Soil compaction decreases soil biodiversity by decreasing microbial biomass, enzymatic activity, soil fauna, and ground flora. (6) Boussinesq equations and finite element method models, that predict the effects of the soil compaction, are restricted to elastic domain and do not
\end{abstract}

M. F. Nawaz $\cdot$ G. Bourrié $\cdot$ F. Trolard

INRA, UR1119, Géochimie des sols et des eaux,

Aix-en-Provence, France

M. F. Nawaz $(\bowtie)$

Department of Forestry, University of Agriculture Faisalabad,

Faisalabad, Pakistan

e-mail: kf_uaf@yahoo.com consider existence of preferential paths of stress propagation and localization of deformation in compacted soils. (7) Recent advances in physics of granular media and soil mechanics relevant to soil compaction should be used to progress in modelling soil compaction.

Keywords Soil compaction · Soil disturbance · Soil stress · Modelling $\cdot$ Soil degradation

Contents

1. Introduction . . . . . . . . . . . . . . . . . 1

2. Causes of the soil compaction ........... 4

3. Quantifying the effects of the soil compaction ......5

4. Effects of compaction on soil chemical properties and biogeochemical cycles . . . . . . . . . . . . . 7

5. Effects of the soil compaction on plants ........ .9

6. Effects of the soil compaction on soil biodiversity. .10

7. Modelling . . . . . . . . . . . . . . 11

8. Remedies to the soil compaction ............14

9. Conclusion . . . . . . . . . . . . . . . 15

\section{Introduction}

Performance of soil on a particular land plays a vital role in the development and survival of civilizations as soil ensures the provision of food and further essential goods for humans (Hillel 2009). But the soil is a nonrenewable resource with potentially rapid degradation rates and extremely slow formation and regeneration processes (Van-Camp et al. 2004). So, the sustainable use of soils is the only solution to deal with the global issues like food security, demands of energy and water, climate change, and biodiversity (Lal 2009; Jones et al. 2009).

Soil degradation is as old as agriculture itself; its impact on human food production and the environment is becoming more serious than ever before because of its extent and intensity (Durán Zuazo and Rodríguez Pleguezuelo 2008). 
Effects of soil degradation are not only on the livelihoods of rural dwellers but it also poses a potential threat to global food supplies over the long term (Scherr and Yadav 1996). Land degradation will remain an important global issue for the twenty first century because of its adverse impact on agronomic productivity, the environment, and its effect on food security and the quality of life (Eswaran et al. 2001). The soil compaction is the physical form of soil degradation that changes the soil structure and influences the soil productivity (Mueller et al. 2010). Unlike salinity, water logging or the soil erosion that can be remarked from the soil surface, the soil compaction causes a hidden degradation of the soil structure that is difficult to locate and rationalize (McGarry and Sharp 2003).

Increased demands for the food and shelter have resulted in mechanization of forests and farms in almost all the developed countries as well as in many developing countries. Mechanized operations involved in intensive cropping and in forest silvi-culture can, directly or indirectly, lead to the soil compaction as shown in Fig. 1 (Ishaq et al. 2001; Silva et al. 2008). About 68 million ha of the soils worldwide are estimated to be affected by the soil compaction from the vehicular traffic. The soil compaction is responsible for the soil degradation in Europe (33 million ha), Africa (18 million ha), Asia (10 million ha), Australia (4 million ha), and some areas of North America (Flowers and Lal 1998; Hamza and Anderson 2003).

The soil compaction can be defined as "the process by which the soil grains are rearranged to decrease void space and bring them into closer contact with one another, thereby, increasing the bulk density" (SSSA 1996). So, the soil compaction involves the changes in physical properties of the soil (bulk density and soil porosity) and these modified physical parameters of the soil are determinants of the influence of the soil compaction on chemical properties of the soil, soil fauna, and diversity and plant growth (Fig. 2).

The soil compaction in cultivated lands affects mostly the upper layer of soil (top soil compaction) but it is also

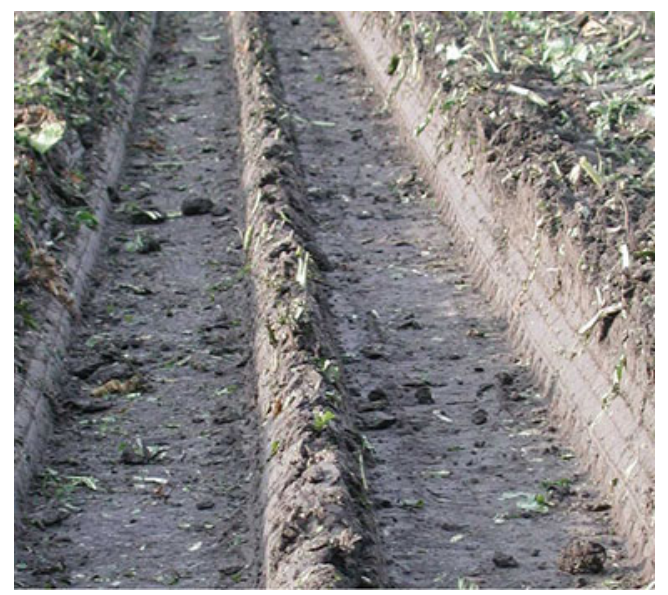

Fig. 1 Ruts formation after the passage of vehicular traffic on soil; an example of compacted soil observed at certain depth (subsoil compaction). Except a few cases where a slight degree of top soil compaction can be beneficial for some type of soils especially sandy soils (Bouwman and Arts 2000), in most cases, it has negative effects on the soil. The subsoil compaction is a serious problem because it is expensive and difficult to alleviate and it has been acknowledged as a serious form of the soil degradation by the European Union (Jones et al. 2003). About 38\% reduction in grain yield of wheat crop is reported when the subsoil compaction was carried out at $0.15 \mathrm{~m}$ depth to a bulk density of $1.93 \mathrm{Mg} / \mathrm{m}^{3}$ (Ishaq et al. 2001). The soil compaction in forests, due to mechanized operations, can be severe but shows more spatial variability than in agricultural lands due to less systemic mechanized operations and presence of stumps and heavy roots in the soil.

A number of reviews already exist on the soil compaction, but they have been written many years back and are focused on specific aspects such as physical aspects of the soil compaction (Horn et al. 1995; Soane et al. 1982), the influence of organic matter on the soil compaction (Soane 1990), modelling the soil compaction (Lipiec and Hatano 2003; O'Sullivan and Simota 1995), and the soil compaction by grazing animals (Drewry 2006).

Some reviewed articles have also discussed the soil compaction on the basis of a specific land use, mainly crop systems (Hamza and Anderson 2005; Soane and Van Ouwerkerk 1995) and rarely forest systems (Greacen and Sands 1980). The most recent review by Batey (2009) focused only on practical soil management issues. In addition to the previous aspects by including the recent studies, this review also considers the effects of the soil compaction on biogeochemical processes and biodiversity, both at macro- and microscales. Furthermore, existing models for the soil compaction are critically discussed and new directions for modelling the effects of the soil compaction on the soil are being proposed

\subsection{Description of the phenomenon}

The soil compaction involves a microscopic rearrangement and bringing of the solid particles closer to one another and consequently an increase in the bulk density of the soil (Panayiotopoulos et al. 1994). But the degree of compactness is a quantitative parameter and defined as "the ratio of the actual bulk density to the reference bulk density obtained by uniaxial compression of wet soil (sufficiently for drainage) at static pressure of $200 \mathrm{kPa}$ " (Håkansson 1990; Lipiec and Hatano 2003). The soil compaction is accompanied by the removal of the soil air, changes in the soil structure, and macroscopic increase in the soil strength (Taylor 1971). The phenomenon of the soil compaction can be explained in the classical elasto-plastic conception of stress-strain phenomena by considering the soil as a material that reacts elastically up to a certain limit of stress; beyond that limit, any incremental 
Fig. 2 Causes of soil compaction and their effects on soil physical properties with ultimate direct effects on soil chemistry, plant growth and soil biodiversity while indirect effects on exchanges of matter with external compartments

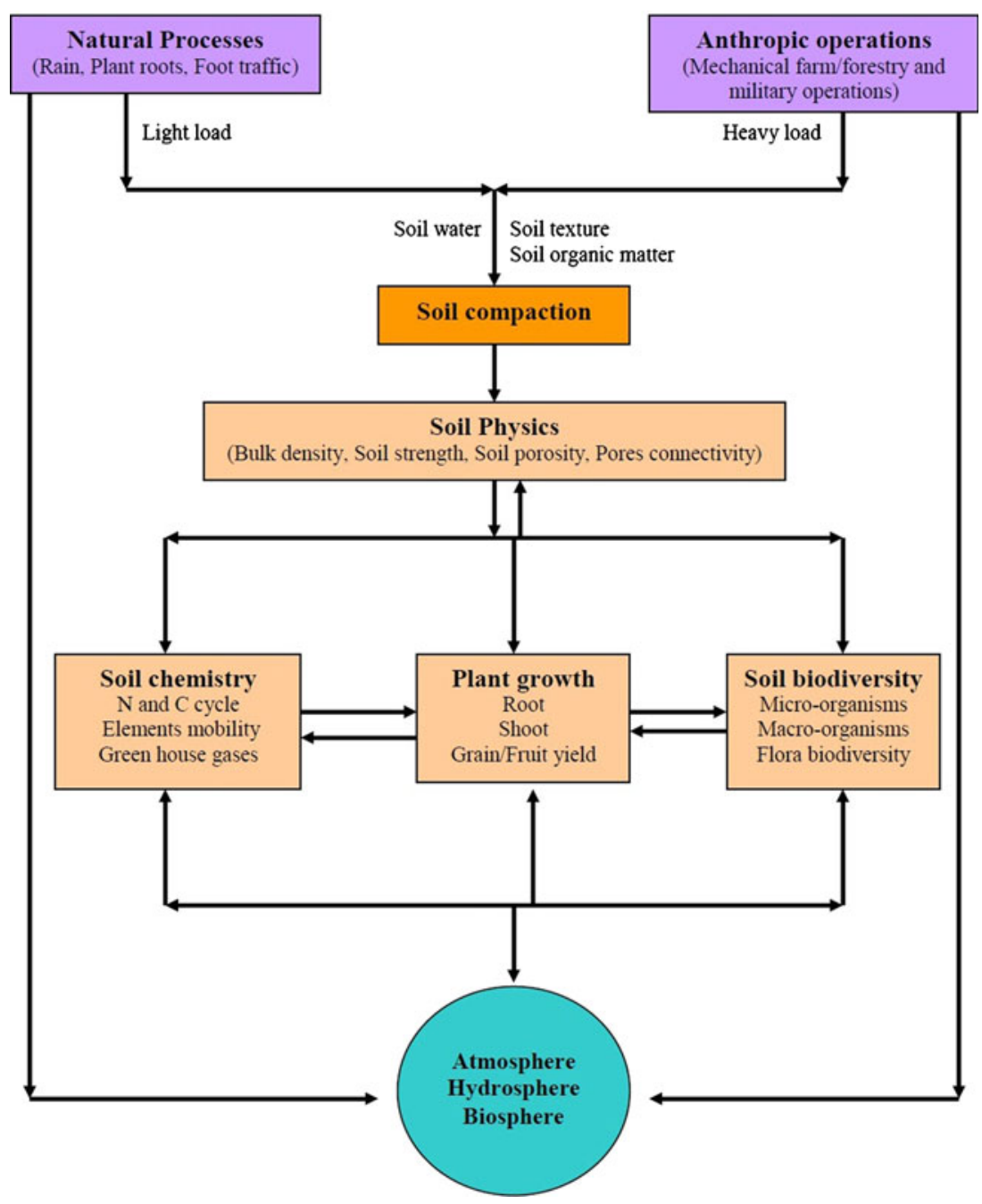

stress results in the plastic deformation (Horn 1988). This stress threshold for a given soil, under given climatic conditions, depends on soil texture, degree of aggregation, and matric potential (Horn et al. 1995). The soil compaction, depending on the soil structure, influences soil physical, chemical, and biological processes (Gupta et al. 1989; Fig. 2).

Susceptibility of the soils to compaction varies with the soil texture. For example, the silt loam soils with low colloid contents are more susceptible than medium or fine textured loamy and clayey soils at low water contents while the sandy soils are slightly susceptible to the soil compaction (Horn et al. 1995). In an experiment, Smith et al. (1997) selected 35 types of soils from timber growing areas covering a wide range of the soil textures (clay contents from $8 \%$ to $66 \%$ ) and organic carbon contents (from $0.26 \%$ to $5.77 \%$ ). A vertical stress was applied on the soils by applying pressure of $0,100,200,400,600,1,000$, and $1,400 \mathrm{kPa}$ at different water contents and then bulk density was measured. Thus, a relationship among pressure applied $(P)$, water content $(W)$, and bulk density of the soil $(D)$ was established. When a loamTypic Haplaquept soil was subjected to varied pressures and moisture contents, it behaved totally differently from a loamy sand-Aquic Ustipsamment soil (Fig. 3). The former one was resistant to the compaction when dried and susceptible to compaction when moist to wet while the latter showed only small increases in compaction at incremental load and the moisture contents. Different behaviour in both types of soil is attributed to higher bulk densities of loamy sand soils when they are very dry due to the particles rearrangement with changing water contents (Smith et al. 1997).

Increases in the soil organic matter may reduce compatibility by increasing resistance to deformation and/or by increasing elasticity (rebound effects; Soane 1990). High organic carbon contents can even reduce the compactibility of soil at high moisture levels in clay and silty clay soils (Smith et al. 1997).

The soil compaction process is highly influenced by the soil water content (Hamza and Anderson 2005; Horn et al. 1995; Mosaddeghi et al. 2000). It affects the penetration 

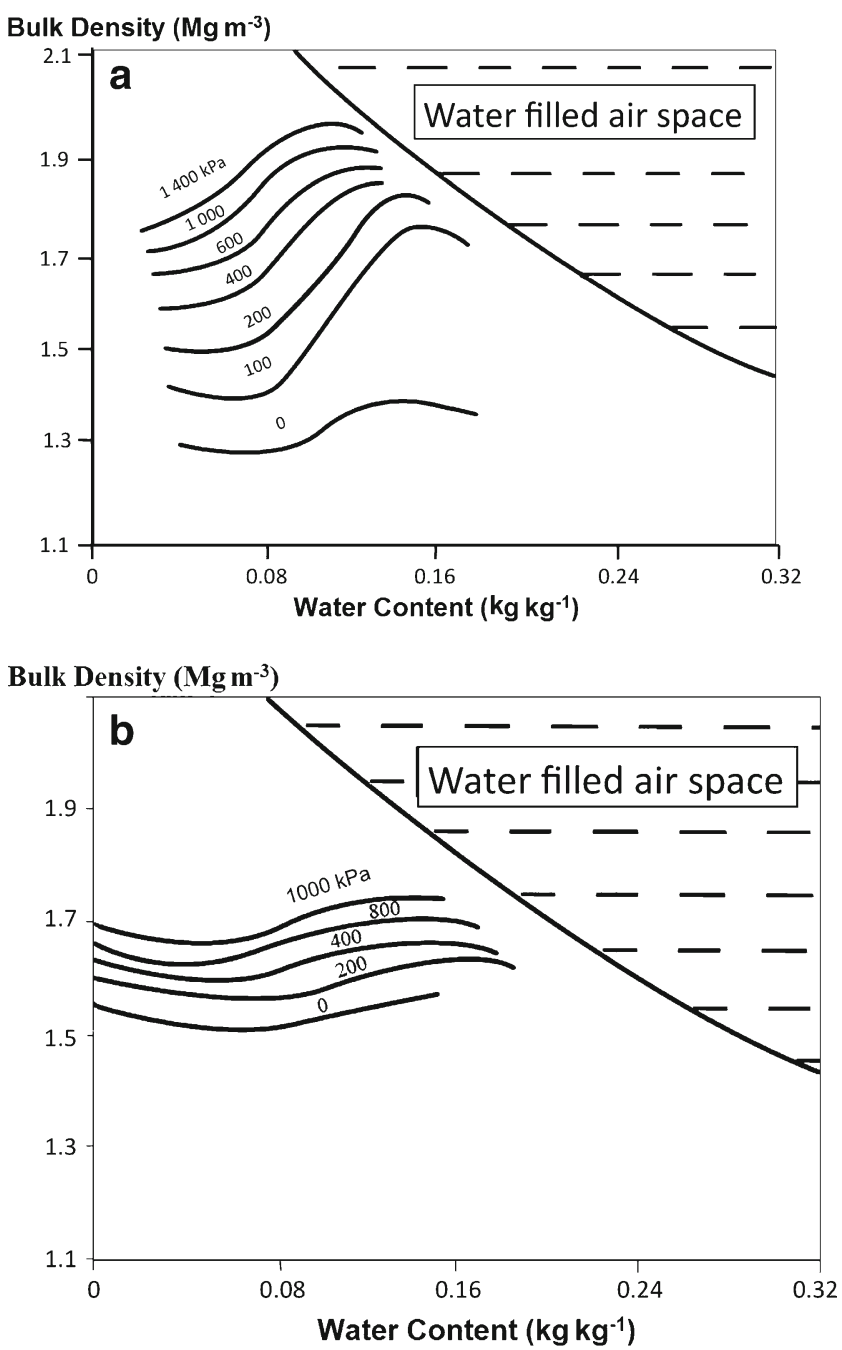

Fig. 3 Contradictory behaviour of two soils with different textures at varied applied pressure and moisture contents. a Loam-Typic Haplaquept, b loamy sand-Aquic Ustipsamment. From Smith et al. (1997)

resistance and load support capacity or maximum permissible ground pressure on the soil (Medvedev and Cybulko 1995). Vulnerability of a soil to compaction at the given soil moisture and energy level depends also on its clay content and mineralogical characteristics (Smith et al. 1997; Wakindiki and Ben-Hur 2002). Generally, a soil with very low moisture content is less vulnerable to compaction than a soil with high moisture content (Gysi et al. 1999). But when the moisture content is so high that all the soil pores are filled with water, the soil becomes less compressible (Smith et al. 1997). Using the bulk density as the soil compaction indicator, Ishaq et al. (2001) showed as to vulnerability of the soil to compaction increases with increasing water contents up to a limit after which it decreases with the increasing water contents (Fig. 4). They carried out a laboratory experiment on the sandy clay loam soil and found that the soil was compacted to its maximum at a soil moisture content of $120 \mathrm{~g} / \mathrm{kg}$. Similar results were reported in another experiment when a vertical

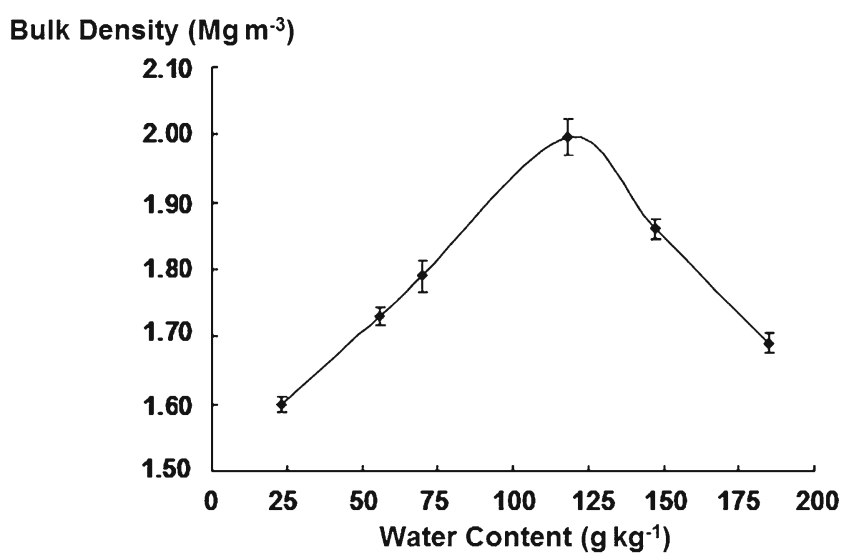

Fig. 4 Relationship between soil water content and bulk density for maximum soil compaction. The error bars represent the standard deviation of mean values. From Ishaq et al. (2001)

pressure was applied on 35 soils of different textures (Smith et al. 1997).

Knowledge of water contents in relation to the soil compaction for a particular soil can be helpful in scheduling the routine mechanical operations on that soil (Batey 2009; Ohu et al. 1989). The soil compaction can also be influenced by the state of energy of water, i.e., water potential, either matric or osmotic potential (Charpentier and Bourrié 1997). In nonsaturated conditions, the suction can influence compaction and the effect of the suction must be separated from the effect of the applied pressure (Cui et al. 2010). So, the soil water contents, soil texture and structure, and soil organic matter are the three main factors among others which determine the degree of compactness after the soil is being exposed to vehicular traffic load.

\section{Causes of the soil compaction}

Compaction can be a natural phenomenon (Fabiola et al. 2003) caused by freezing and drying or an artificial phenomenon caused by the mechanical operations (Greene and Stuart 1985). Conventional agricultural practices can also degrade the soil by the soil compaction (Quiroga et al. 1999).

In modern agriculture, most of the field operations from sowing to harvesting are done mechanically by using heavy wheeled machines which can compact the soil at every passage (Williamson and Neilsen 2000). The soil compaction by a machine, in general, depends on the soil strength and loading of machine (Alakukku et al. 2003). The soil strength is influenced by the organic matter, water content, soil structure, and texture while the loading is expressed by axle load, number of tyres, tyre dimensions, tyre velocity, and soil tyre interaction (Kirby et al. 1997; Sakai et al. 2008). Axle load should not be confused with axle pressure as axle load is weight of machine 
(kilogram) while pressure is the axle load per unit surface area (kilopascal) and in the soil compaction; the term pressure is used to express the disturbance on a soil. Increasing the pressure on the soil increases the chances of the soil compaction (Gysi et al. 1999). Increasing the frequency of passages of machines over a soil increases its dry bulk density and cone index resulting in the top soil compaction and unsuitable physical soil conditions for seed emergence (Botta et al. 2006; Sakai et al. 2008). However, a major portion of the total soil compaction is caused by the first passage (Bakker and Davis 1995; Silva et al. 2008) or early passages (Sakai et al. 2008) of the machine and 10 passes can affect the soil up to $50 \mathrm{~cm}$ depth (Hamza and Anderson 2005).

Animal trampling can cause the soil compaction and can degrade the soil structure (Silva et al. 2003). The soil compaction caused by grazing animals through hoof action is likely to be more widespread within the paddocks as compared to the soil compaction caused by mechanical implements which is limited under the tracks (Drewry 2006; Sigua and Coleman 2009). Physical deterioration by grazing animals depends on the trampling intensity, soil moisture, plant cover, land slope, and land use type. Animal caused the soil compaction could range from 5 to $20 \mathrm{~cm}$ and might affect the soil bulk density, hydraulic conductivity, macropore volume, and penetration resistance of the soil (Hamza and Anderson 2005; Sigua and Coleman 2009). Effects of the grazing animals on the soil physical properties (Drewry et al. 2008), and soil nitrogen and carbon have been discussed in detail in literature (Bhandral et al. 2007; Piñeiro et al. 2010).

In contrast to the cultivated lands, harvesting operations in forest cause more soil compaction because of: (1) the use of heavy machinery for harvesting; (2) felling, pushing, pulling, and lifting of logs; (3) during transport of logs that exert a combined pressure on the soil; (4) no tillage operations in forests to loosen the soil. In the forests, harvesting operation causes different types of the soil disturbances and probability of the soil compaction is directly related to harvesting system and harvesting density (Sowa and Kulak 2008). Mostly severe soil compaction is caused when thinning and clear felling operations are carried out with machines and these operations can compact the soil up to the depth of $60 \mathrm{~cm}$ leaving the effects for more than 3 years (Greacen and Sands 1980). A simple logging operation in the forests can damage $20-30 \%$ of the forest land up to the depth of $30 \mathrm{~cm}$ (Herbauts et al. 1996). The use of light weight multifunctioning machines can reduce the passages and ultimately the degradation of the soil (Radford et al. 2000).

In the urban areas, urban parks and recreational sites receive large number of visitors and with increasing urban population, visitors' pressure on these sites is increasing day by day (Frick et al. 2007). Trampling effects of the visitors on the soil and vegetation have been reported by many authors (Jim 1987; Sarah and Zhevelev 2007) and these effects are long term in some cases (Kissling et al. 2009). Increasing visitors' pressure results in the soil compaction, increased bulk densities, decreased soil porosity and decreased organic matter contents (Marion and Cole 1996; Sarah and Zhevelev 2007).

Military operations or military training exercises in the past have also resulted in severe soil compactions in some places (Silveira et al. 2010) and increased bulk density of the soils up to $2.12 \mathrm{Mg} / \mathrm{m}^{3}$ has been reported due to military operations (Webb 2002).

Natural causes (tree roots, precipitation, seasonal cycles, etc.) of the soil compaction are not as harmful as anthropogenic causes: the soil compaction associated with natural causes is limited in top $5 \mathrm{~cm}$ of the soil and the soil compaction due to the trampling and urban pressure on a site can compact the soil up to $20 \mathrm{~cm}$ while mechanical operations can compact the soil up to $60 \mathrm{~cm}$. No matter of which origin it is, the soil compaction influences the water dynamics (Schlotzhauer and Price 1999), pesticide diffusion (Alletto et al. 2010; Van den Berg et al. 1999), soil erosion (Kosmas et al. 1997), carbon and nitrogen cycle (De Neve and Hofman 2000), plant growth (Lowery and Schuler 1991), and mechanical operations cost (Soane and Pidgeon 1975); as we shall discuss in the coming sections.

\section{Quantifying the effects of the soil compaction}

To characterize the soil compaction, physical parameters such as the bulk density and porosity, soil strength, water infiltration rate, and reduction of aeration have been used. Indeed, under natural conditions, due to steady-state aggregation processes, and biological processes, the soil contains a large proportion of macropores. The soil compaction can result in the destruction of inter-aggregate pores, in the reduction of soil hydraulic conductivity and air permeability (Horn et al. 1995). Macropores are relatively more affected during the soil compaction than micropores.

\subsection{Bulk density and porosity}

Bulk density (dry soil mass per unit volume) is the most frequently used parameter to characterize the soil compaction (Panayiotopoulos et al. 1994), but in swelling/shrinking soil, it is recommendable to determine the bulk density at the standard moisture contents (Håkansson and Lipiec 2000). Typical resistance indicators, used nowadays, are highly precise for the soil density measurements up to the soil depth of $20 \mathrm{~cm}$ while for deep stratum, the stress state transducers with six earth pressure gauges that measure three dimensional stresses can be useful (Eguchi and Muro 2007). The bulk density is difficult to measure in gravelly soils (Webb 2002). For an accurate measurement of the effects of the soil compaction on all types of the soil, the soil bulk density alone is not adequate but other soil properties such as the soil strength, soil aeration, and soil moisture should also be measured (Lipiec and Hatano 2003). 
In an experiment on a clayey oxisol, Silva et al. (2008) analyzed the effects of the intensity of traffic on the soil compaction. They removed the 7-year-old Eucalyptus stand manually with chainsaw and soil was compacted with forest tractor, weighing $11,900 \mathrm{~kg}$ and loaded with $12 \mathrm{~m}^{3}$ wood, by driving along same track zero, two, four, and eight times. They found that the first two passes of forwarder caused maximum increase in the bulk density and maximum decrease in infiltration rate. In other experiments, $30 \%$ increase in bulk density was observed after mechanical clearing of the forests (Weert 1974 ) and $20 \%$ increase in the bulk density was found after tree length skidding in pine hardwood stands (Dickerson 1976).

Decrease in the soil porosity has been widely reported in the cultivated crops and forests after mechanical operations (Dickerson 1976; Silva et al. 2008). Herbauts et al. (1996) showed that a logging operation, in the loamy and acidic soils with an illuvial and frequently mottled argillic B horizon, has increased the bulk densities and decreased the total porosity of the soils up to $30 \mathrm{~cm}$ depth at two different sites, Terrest and Tumuli (Table 1). It is reported that an increase in contact pressure of $100 \mathrm{kPa}$ caused a decrease of $5.7 \%$ in the soil porosity at $10-15 \mathrm{~cm}$ depth after 24 passes in the sandy humus rich forest soil (Sakai et al. 2008).

\subsection{Soil strength}

The soil strength (resistance to penetration) is also widely used for the soil compaction measurement (Bouwman and Arts 2000;
Horn and Rostek 2000; Taylor 1971). The soil strength increases with increasing bulk density while it decreases with decreasing soil moisture content. One should be careful when measuring penetration resistance because it varies between the seasons due to different moisture contents (Bouwman and Arts 2000).

The soil strength is measured by a penetrometer (Usowicz and Lipiec 2009) and, furthermore, cone penetrometer is widely employed (Yu and Mitchell 1998) to measure the soil strength in terms of cone resistance (megapascals). The cone resistance also serves as an indicator of the root penetration and root growth capabilities (Materechera and Mloza-Banda 1997). Sinnett et al. (2008) reported that a soil having a cone resistance larger than $3 \mathrm{MPa}$ caused a major hindrance for the root penetration of four tree species (Japanese larch, Italian alder, birch, and Corsican pine) in the sandy loam soils as shown in Fig. 5; nearly all roots $(90.7 \%)$ were present in the soil with a cone resistance class less than $3 \mathrm{MPa}$.

\subsection{Water infiltration rate}

Soil water infiltration rate can also be used to monitor the soil compaction status because the soil compaction reduces the total porosity of the soil (Silva et al. 2008), and mainly the number of macropores, water infiltrates faster in uncompacted soil than in a massively compacted soil of the same type (Hamza and Anderson 2003). These are not directly related to the changes in porosity but rather to the changes in both the number of macro-pores and in the connectivity between
Table 1 Bulk density and total porosity of eluvial and illuvial horizons in the beech stands studied (undisturbed vs. rutted soils)

Mean values at two different sites (Terrest site, $n=10$; Tumuli site, $n=30$ ) are given with standard deviations. From Herbauts et al. (1996)

$* P<0.05, * * P<0.01$, $* * * P<0.001$

\begin{tabular}{lll}
\hline Horizon & Depth $(\mathrm{cm})$ & $\begin{array}{l}\text { Bulk density }\left(\mathrm{kg} \mathrm{dm}^{-3}\right) \\
\text { Core method }\end{array}$
\end{tabular}

\section{Terrest $n=10$}

Undisturbed soil

E

$B_{t}$

$10-30$

$1.37 \pm 0.08$

$48.4 \pm 3.1$

$30-50$

$1.66 \pm 0.04$

$37.3 \pm 1.6$

$E_{g}$

$10-30$

$1.54 \pm 0.10$

$41.8 \pm 3.6$

$B_{t g}$

$30-50$

$1.58 \pm 0.08$

$40.2 \pm 3.2$

Tumuli $\boldsymbol{n}=\mathbf{3 0}$

Undisturbed soil

E

$B_{t}$

10-30

$1.31 \pm 0.10$

$50.6 \pm 3.8$

$1.54 \pm 0.06$

$42.1 \pm 3.8$

Rutted soil

$E_{g}$

10-30

$1.62 \pm 0.07$

$38.9 \pm 2.8$

$B_{t g}$

$30-50$

$1.54 \pm 0.05$

$41.8 \pm 1.8$

Bulk density (core method)

Unpaired $t$ test

$E$ vs. $E_{g}$

Terrest
$-4.363 * * *$
$2.584 *$

Tumuli

$-13.607^{* * *}$

$B_{t}$ vs. $B_{t g}$
NS 
Fig. 5 Mean percentage of roots in each penetration resistance class using the penetrometer; $90.7 \%$ of roots are present in penetration resistance class less than $3 \mathrm{Mpa}$. From Sinnett et al. (2008)

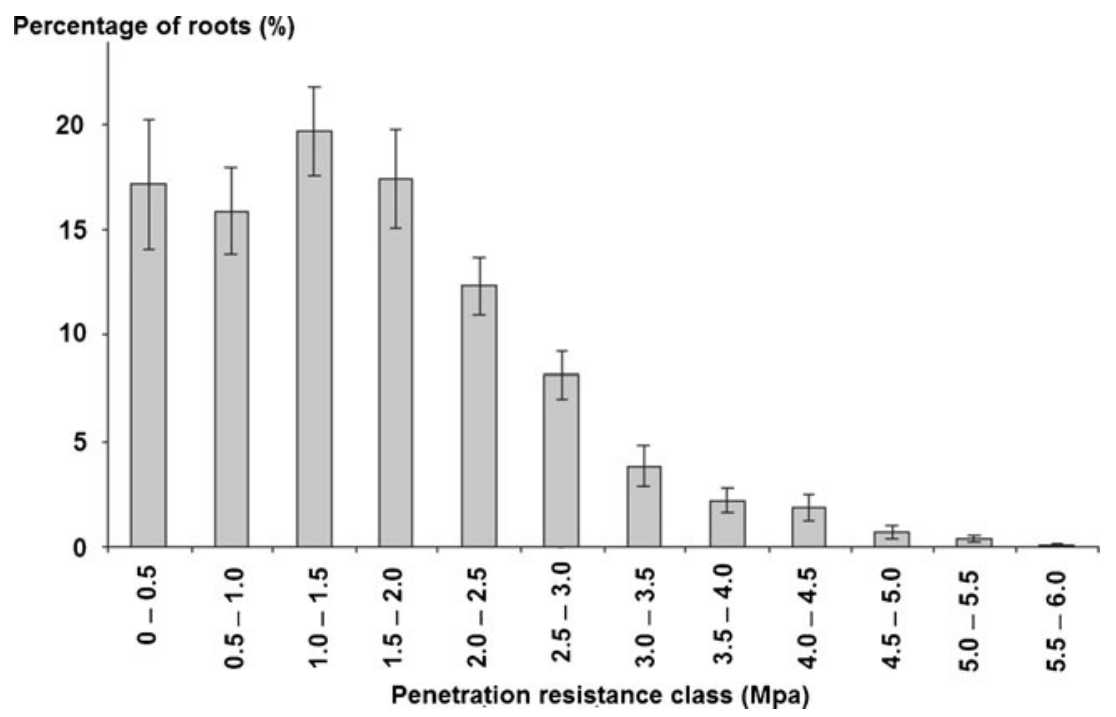

macropores (see below). Such changes in tortuosity can influence the soil electrical conductivity (Seladji et al. 2010).

\subsection{Reduction of aeration}

Reduced soil aeration can be an indication of the soil compaction and soil aeration can be quantified by different parameters such as the air filled porosity, oxygen diffusion rate (ODR), redox potential, and air permeability (Cannell 1977). Air permeability varies largely according to the soil physical properties for the same level of compaction while the measurement of ODR by electrode needs a lot of care. Redox potential measurements can be a good tool to characterize the compacted soils as these measurements can be carried out in situ for the long periods, but this method is only applicable to the very wet soils (close to or at saturation; Feder et al. 2005; Lipiec and Hatano 2003; Nawaz 2010).

Among different methods discussed, the soil bulk density and the soil strength are more commonly employed to quantify the soil compaction but the use of other indicators like water infiltration rate, ODR, redox potential, etc. in combination with them can largely increase our understandings and results precisions. Now sensors have also been developed to detect the location and depth of the hard pans in the real time that are equipped with four horizontal operating penetrometers for on-the-go sensing and mapping of the location and intensity of hard pan (Loghavi and Khadem 2006). Sensor systems to measure the soil compaction have already been reviewed (Hemmat and Adamchuk 2008).

\section{Effects of compaction on the soil chemical properties and biogeochemical cycles}

\subsection{Reductive conditions}

Modified soil physical properties due to the soil compaction such as the reduced water infiltration rate and reduced soil air permeability also influence the soil chemical properties. The soil compaction causes decrease in oxygen diffusion (Renault and Stengel 1994) and can lead to anoxic conditions in compacted soils if consumption of oxygen is faster than diffusion (Schnurr-Putz et al. 2006). At the same time, due to the reduced water infiltration rate, the soil compaction can result in the surface water logging in the wheel ruts covered areas during the wet seasons that can influence all the pedological processes, especially iron geochemistry (Munch and Ottow 1983).

Surface water logging and absence of oxygen, in compacted soils; result in the lowering of redox potentials of soil solution, formation of reduced forms of iron $\left(\mathrm{Fe}^{2+}\right.$; Ponnamperuma 1985), increased dissolution of iron hydroxides and increase in organically complexed iron forms. Presence of iron minerals such as lepidocrocite that indicates hydromorphy can be observed in compacted soils by naked eye due to orange colours of mottles but detection of these iron minerals by X-ray diffraction (XRD) is not evident (Herbauts et al. 1996). In one experiment, Herbauts et al. (1996) reported higher concentrations of easily reducible iron $\mathrm{Fe}^{2+}$ in the above $30 \mathrm{~cm}$ of the soils after a logging operation in a forest land (Fig. 6). Exchangeable $\mathrm{Fe}^{2+}$ was extracted from a freshly sampled soil with a hydroxylamine/potassium chloride solution and determined colorimetrically using orthophenanthroline. They directly correlated the presence of $15-30 \%$ of free iron in the form of easily reducible form $\mathrm{Fe}^{2+}$ with the water logging as the result of the soil compaction. Selective extraction techniques using citratebicarbonate and citrate-bicarbonate-dithionite showed that the soil compaction under forest resulted in an increase of readily extractable $\mathrm{Fe}$ oxides after only 2 years, before mineralogical transformations were detectable by XRD (Nawaz 2010).

\subsection{Carbon and nitrogen cycles}

The soil compaction affects concentration of carbon dioxide (Conlin and Van den Driessche 2000) and mineralization of 


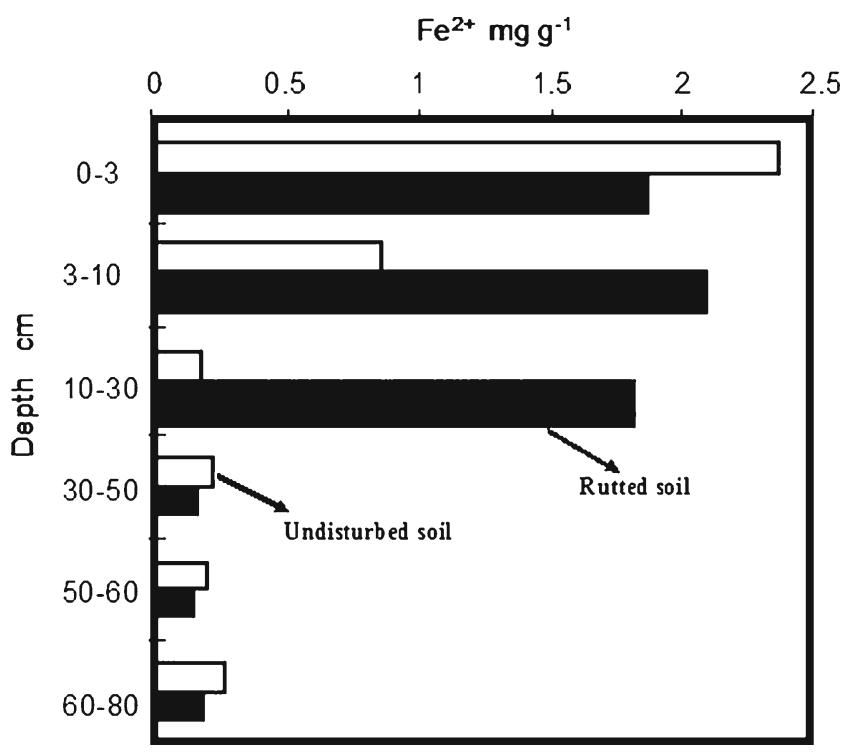

Fig. 6 Profile distribution of easily reducible iron $\left(\mathrm{KCl}-\mathrm{NH}_{2} \mathrm{OH}-\right.$ extractable $\mathrm{Fe}^{+2}$ ) in undisturbed (transparent rectangles) and rutted soil (dark black rectangles). From Herbauts et al. (1996)

the soil organic carbon and nitrogen in the soil (De Neve and Hofman 2000). In a laboratory experiment, when silt loam (acid forest soil) was compacted artificially to a bulk density of 1.5 from $1.1 \mathrm{Mg} / \mathrm{m}^{3}$, a significant reduction in the carbon mineralization and net nitrification rates was observed after 9 months (Tan and Chang 2007). The soil compaction, directly, results in the lower efflux of $\mathrm{CO}_{2}$ from compacted soils (Silveira et al. 2010) but, indirectly, due to increase of machinery use to plough the compacted soil, can lead to more consumption of the fuel and ultimately more emission of $\mathrm{CO}_{2}$ (Voorhees and Hendrick 1977).

Denitrification increases with the soil compaction (Arah and Smith 1989) that results in the increased emission of $\mathrm{N}_{2} \mathrm{O}$ to the atmosphere (Douglas and Crawford 1993). These emissions can be much larger in the cultivated fields if $\mathrm{N}$ fertilizer is applied in wet conditions (Clayton et al. 1994). In fact, in the soils, $\mathrm{N}_{2} \mathrm{O}$ is produced by both the nitrification (aerobic soil conditions) and denitrification (anaerobic soil conditions) and sometimes the nitrification and denitrification can occur simultaneously in the same soil aggregate (Davidson et al. 1986). As the soil compaction results in the increase of water contents, so, it can increase strongly denitrification processes in the soil (Maag and Vinther 1996). Soane and Van Ouwerkerk (1995) have reported that the soil compaction can cause an increase in the denitrification rate and emissions of $\mathrm{N}_{2} \mathrm{O}$ about $400-500 \%$. But, in compacted soils, there is a possibility of decrease of $\mathrm{N}_{2} \mathrm{O}$ transport to atmosphere and decreased reduction of $\mathrm{N}_{2} \mathrm{O}$ to $\mathrm{N}_{2}$ gas, a harmless gas, depending upon the residence time of $\mathrm{N}_{2} \mathrm{O}$ in the soil and soil conditions (Soane and Van Ouwerkerk 1995).

It is reported that emission of $\mathrm{N}_{2} \mathrm{O}$ after fertilization is highly dependent on the rainfall (Ball et al. 1999; Fig. 7). In their experiment, the soil was compacted by increased tractor weight up to a bulk density of 1.40 and $1.39 \mathrm{Mg} / \mathrm{m}^{3}$ at $0-100$ and $100-250 \mathrm{~mm}$ depths, respectively, as compared to normal bulk densities of 1.21 and $1.26 \mathrm{Mg} / \mathrm{m}^{3}$ at the same depth, respectively. It is clear from Fig. 7 that heavy compaction treatment gave greater response in term of $\mathrm{N}_{2} \mathrm{O}$ emission to rainfall than the zero compaction treatment. Bessou et al. (2010) tried to model the emission of $\mathrm{N}_{2} \mathrm{O}$ gas after the soil compaction, but their model was not capable of capturing the emission during the cropping cycle.

The soil compaction reduces the available $\mathrm{N}$ (Tan et al. 2008) and efficiency of N use by the crops decreases (Douglas and Crawford 1991), which can increase the fertilizer requirements. It is reported that the soil compaction which ultimately increases the water contents and denitrification processes in the soil, likely reduces the emissions of $\mathrm{NO}_{\mathrm{x}}$ from the soil (Skiba et al. 1994) but increases the volatilization of ammonia, as compared to uncompacted soils (Soane and Van Ouwerkerk 1995).

The soil compaction favours the anaerobic soil conditions which can result in the increase in methanogenic (methane producer) bacteria while decrease in the methanotrophic (methane oxidising) bacteria (Yao et al. 1999). The soil compaction will result in the higher production rate of $\mathrm{CH}_{4}$ than its oxidation or destruction rate and this destruction rate can be reduced up to $58 \%$ when well drained soils are compacted (Soane and Van Ouwerkerk 1995).

\subsection{Environmental impacts of the soil compaction}

Local soil compaction can influence not only the soil but also the local environment (Soane and Van Ouwerkerk 1995). The emissions of greenhouse gases due to the soil compaction $\left(\mathrm{N}_{2} \mathrm{O}, \mathrm{CH}_{4}\right.$, and $\left.\mathrm{CO}_{2}\right)$, as discussed in Section 4.2 can enhance the greenhouse effect. The soil compaction results in increased energy costs in the cultivated lands due to the increased fertilizer inputs and greater tillage requirements. However, it can also be responsible for energy savings, in some soils, due to increase in machine efficiency in rolling over compacted soils (O'Sullivan and Simota 1995). Anaerobic conditions in the soil due to the soil compaction can result in reduced decomposition of pesticide and ultimately increased leaching of pesticide in groundwaters and aquifers (Alletto et al. 2010). Similarly, decreased hydraulic conductivities can result in slow downward movement of water and, ultimately, more nitrate contents in ground waters.

If the soil compaction is carried out in steep slopes, this can result in increased runoff and ultimately in increase soil erosion and sediment transport which could be a serious problem for the landscape. Furthermore, increased runoff, in slurry applied fields, can result in the entrance of slurry in surface waters and ultimate threat to the aquatic life as degradation of slurry can reduce the oxygen levels in surface 
Fig. 7 Temporal variability of $\mathrm{N}_{2} \mathrm{O}$ fluxes and 3-hourly rainfall in heavily compacted soil and uncompacted soil under winter barley, shortly after the main spring fertilisation of $110 \mathrm{kgN} / \mathrm{ha} /$ year, assessed using the automatic chambers. From Ball et al. (1999)

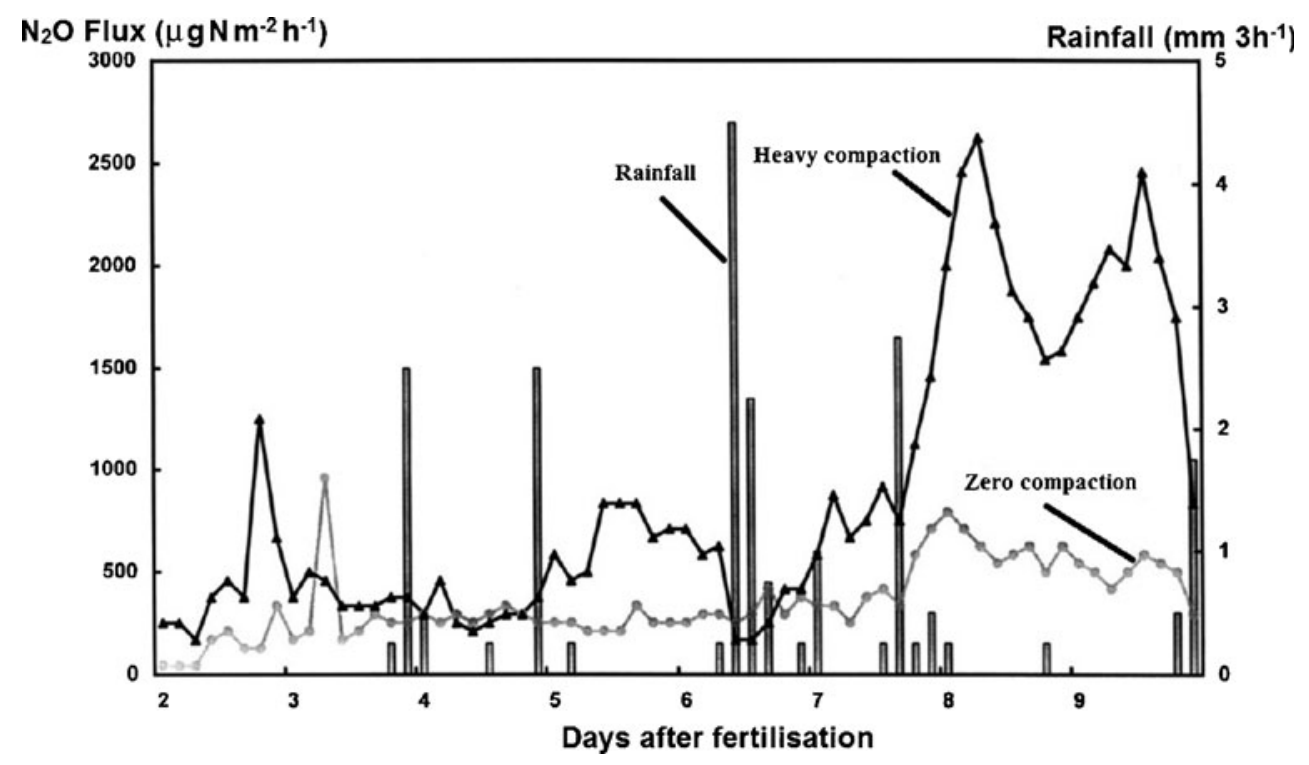

waters. However, in some soils (sandy soils), the soil compaction increases the soil strength, erodibility, and consequently the soil erosion for the same amount of runoff is reduced. So, modified soil physical properties due to the soil compaction can be beneficial or harmful for the environment depending upon the existing environmental conditions and physical properties of the soil before modification.

\section{Effect of the soil compaction on plants}

Overall effect of the soil compaction on the plant yield is negative (Ishaq et al. 2001; Saqib et al. 2004a) but it can also result in no effect or yield increase as reviewed by Greacen and Sands (1980). The soil compaction results in the restricted root growth, decreased accessibility of nutrients, and increased loss of the soil nutrients by leaching, runoff, and gaseous losses to atmosphere which can affect plant growth. Effects of the soil compaction on uptake and losses of nutrients have already been reviewed (Lipiec and Stepniewski 1995). If a soil is already suffering from other types of degradation such as the salinity, drastic effects of the soil compaction on the plant growth and crop yield are reported to be doubled (Saqib et al. 2004a).

\subsection{Roots}

Roots play an important role in the nutrient uptake and plant growth (Marschner 1986). Root penetration ability is adversely affected by the soil compaction due to increased soil strength and decreased number of macropores (Gerard et al. 1982). Soil strength-root relation is well documented and reviewed in literature (Hamza and Anderson 2005; Kirby and Bengough 2002; Masle and Passioura 1987; Taylor et al. 1966; Taylor and Ratliff 1969; Voorhees et al. 1975). Effects of the soil compaction on roots generally vary with interspecies and for different cultivars of the same species, due to difference in root penetration ability depending on the root physiology and morphology (Materechera et al. 1991; Tardieu 1994).

Generally, compaction results in a decrease in the root length, root penetration, and rooting depth (Glinski and Lipiec 1990; Kristoffersen and Riley 2005). It is reported that the compaction of calcareous loamy soils, having 5\% organic matter, with a load of $14.5 \mathrm{Mg}$ resulted in complete failure of the root penetration in the deeper soils $(>20 \mathrm{~cm}$; Bouwman and Arts 2000). The soil compaction can also aggravate a root disease in some species of plants (Fritz et al. 1995). Top soil compaction is a more limiting factor for the root growth than the subsoil compaction (Botta et al. 2006). The effects of the soil compaction on the ion uptake and root growth are more severe in saline soils than in normal soils. Saqib et al. (2004b) found that the compaction of a sandy clay loam soil to a bulk density of 1.65 from $1.21 \mathrm{Mg} / \mathrm{m}^{3}$ reduced root length density of wheat plants while the presence of salinity $(15 \mathrm{dS} / \mathrm{m})$ was more drastic than the soil compaction alone. In the same experiment, they observed greater reductions in $\mathrm{K}^{+}$concentrations and the $\mathrm{K}^{+} / \mathrm{Na}^{+}$ratio in leaves due to interaction of salinity and compaction.

The roots of some cover crops have shown good penetration ability and less adverse effects of the soil compaction. These crops can be used to alleviate the effects of the soil compaction (Rosolem et al. 2002). Because of larger diameters of roots than soil pores, roots can also increase the bulk density of the soil near the roots during the root penetration (Dexter 1987) and this phenomenon can change the physical, biological, and chemical aspects of the soil near the roots (Glinski and Lipiec 1990). Change in micro- and mesoporosity around roots can also be quantified by scanning electron microscopy (Bruand et al. 1996). 


\subsection{Shoots}

Although rooting system of the plants is badly affected by the soil compaction, this does not always result in reduced shoot growth because it depends on the availability of nutrients in the soil. If a soil is so heavily compacted that it reduces the mobility of the ions in soil and severely restricts the root growth; it can limit the shoot growth. Ishaq et al. (2001) and Silva et al. (2008) observed no effects of the soil compaction on the plant height but reduction in the grain yield was reported by Ishaq et al.(2001).

\subsection{Seedling emergence}

Seedling emergences are adversely affected by the soil compaction (Dürr and Aubertot 2000). The soil compaction is more detrimental to the seedling growth and survival as compared to established plants and trees. Increase in the bulk density of a dry soil from 1.3 to $1.8 \mathrm{Mg} / \mathrm{m}^{3}$ in a greenhouse experiment resulted in the late emergence of oak seedlings and a mortality rate of $70 \%$ (Jordan et al. 2003). In the same experiment, they found that the soil compaction resulted in reduced height of the young seedlings and reduced $\mathrm{N}$ recovery. Similar findings were reported by different authors in the pot experiments and field experiments (Corns 1988; Moehring and Rawls 1970; Tworkorski et al. 1983). But the response of seedlings growth to the soil compaction is also subjected to the soil types and plant species because sometimes moderate compaction of sandy soils can be useful to the seedlings growth of woody plant species (Alameda and Villar 2009).

\subsection{Nutrients uptake}

Generally, the soil compaction reduces the uptake of nutrients due to the damaged roots but it also increases the contact between the roots and soil particles which may lead to the rapid exchange of ions between the soil matrix and roots. The uptake of nutrients transported by diffusion is more affected by compaction than for nutrients transported by mass flow (Arvidsson 1999). The soil compaction can decrease the uptake of phosphorus and potassium in the maize (Dolan et al. 1992) or can increase the uptake of phosphorus in the ryegrass and maize (Shierlaw and Alston 1984) depending on the type of the soil and nature of the soil compaction. Kristoffersen and Riley (2005) subjected three types of soils (loam, clay loam, and silt) to relative degree of compactness (RDC) of $75 \%$ (RDC75\%) and 90\% (RDC90\%) of the standard degree of compactness. They observed that heavy soil compaction reduced the $\mathrm{P}$ uptake and yield of barley in all three types of the soils (Table 2).

So, the soil compaction negatively affects the root portion of the plants but ultimate effect on the shoot depends on the nutrient availability and uptake by the plants. However,
Table 2 Effects of the relative degree of soil compactness (RDC) on barley shoot yield (gdrymatter/pot) and on $P$ uptake $(\mathrm{mgP} / \mathrm{pot})$ in the three soil groups

\begin{tabular}{|c|c|c|c|c|}
\hline & & Loam & Clay loam & Silt \\
\hline \multirow[t]{3}{*}{ Shoot yield $\left(\mathrm{g} \mathrm{pot}^{-1}\right)$} & $\mathrm{RDC}_{75 \%}$ & 8.6 & 5.6 & 4.8 \\
\hline & $\mathrm{RDC}_{90 \%}$ & 7.4 & 4.8 & 3.4 \\
\hline & $p$ Value & 0.03 & 0.001 & 0.006 \\
\hline \multirow[t]{3}{*}{ P uptake (mg pot $\left.{ }^{-1}\right)$} & $\mathrm{RDC}_{75 \%}$ & 28.9 & 11.9 & 8.9 \\
\hline & $\mathrm{RDC}_{90 \%}$ & 24.2 & 10.2 & 7.0 \\
\hline & $p$ Value & 0.005 & 0.003 & 0.02 \\
\hline
\end{tabular}

From Kristoffersen and Riley (2005)

severe soil compaction can result in the root deformation, stunted shoot growth, late germination, low germination rate, and high mortality rate. All these impacts of the soil compaction contribute largely in reducing the yield of most agronomic crops in compacted soils.

\section{Effect of the soil compaction on soil biodiversity}

Modified soil physical parameters determine the effect of the soil compaction on physical and chemical properties of the soils and ultimately on soil biota. The soil compaction can be favourable to soil biodiversity and vice versa depending upon the nature of the soil, climate, and extent of the soil compaction. Beylich et al. (2010) reported the negative influence of the soil compaction on microbial biomass and $\mathrm{C}$ mineralization above an effective bulk density of $1.7 \mathrm{Mg} / \mathrm{m}^{3}$.

\subsection{Bacterial population}

Soil microbial biomass is adversely affected by the soil compaction (Frey et al. 2009; Pupin et al. 2009). The soil compaction resulted in reduced soil aeration of the soil due to $13-36 \%$ decrease of air filled porosity which led to the reduction in microbial biomass carbon and microbial biomass nitrogen (Tan and Chang 2007). Tan et al. (2008) also reported the reduction of microbial biomass phosphorus after the soil compaction. Shestak and Busse (2005) reported that the soil strength values ranging 75-3,800 $\mathrm{kPa}$ changed the physical properties of the soil but did not affect any biological indicator of the soil (microbial biomass and enzymatic activity).

\subsection{Enzymatic activity}

Any disturbance or stress to the soil can influence enzymatic activities in the soil (Buck et al. 2000). The soil compaction changes physical and chemical properties of the soil which leads to the reduction of phosphatase, urease, amidase, and 
dehydrogenase activities (Dick et al. 1988; Jordan et al. 2003; Pupin et al. 2009; Tan et al. 2008), but sometimes increase in the phosphatase activity is also reported (Buck et al. 2000). Anoxic conditions in the soil induce the changes in the microbial community and favour organisms capable of tolerating these conditions, thus, lower eukaryotic/prokaryotic ratios, more iron and sulphate reducers, and higher methanogens were found in compacted soils than in uncompacted soils (Schnurr-Putz et al. 2006).

\subsection{Larger soil fauna}

Soil fauna plays an important role in the decomposition and incorporation of organic matter in the soil (Petersen and Luxton 1982). Habitat of the soil fauna is interstitial spaces in the soil. The soil compaction changes the pore size availability and distribution which generally leads to the reduction of the proportion of large pores and affects the movements of nematodes and larger soil fauna. Nematodes, being diverse in food habit (bacterivores, herbivores, and omnivores), play an important role in the soil food web as well as in organic matter decomposition, nutrient decomposition and herbivory (Bouwman and Arts 2000). Heavy soil compaction may not affect the quantity of nematodes in the soil but can influence their distribution. Bouwman and Arts (2000) reported reduction of bacterivore and omnivore nematodes while increase of herbivore nematodes in heavily compacted soils. Earthworms are also reported to be influenced by the soil compaction (Kretzschmar 1991; Radford et al. 2001) and their population decreases with increase in the soil compaction (Chan and Barchia 2007), but they are capable to penetrate a soil with penetration resistance of 3,000 $\mathrm{kPa}$ by ingesting the soil particles (Dexter 1978).

\subsection{Ground flora}

Ground flora is very important in the forest ecosystem in terms of revegetation, productivity, aesthetics, and water and nutrient cycling (Gilliam 2007). Any disturbance to the forest ecosystem and/or soil affects adversely the native ground flora (Zenner et al. 2006; Demir et al. 2008), but some plant species are capable to show healthy habitat and a rapid recovery after extreme degradation of the soil (Demir et al. 2008). Zenner and Berger (2008) reported that the soil compaction resulted in shifting of ground flora from interior forest species to noxious/invasive and disturbed forest species and relative resistance of the initial ground flora to change was found to be linearly related to relative resistance to penetration. The soil compaction influences the soil biodiversity negatively and it results in decrease in the microbial biomass, enzymatic activity, soil fauna, and ground flora in compacted soils.

\section{Modelling}

Modelling not only provides a better way to quantify the processes involved in the soil compaction but also helps us to predict the vulnerability of a particular soil to compaction. It (modelling) is useful in the organisation and integration of existing knowledge and identification of gaps in knowledge. It (modelling) is a simulation of all the processes involved in the soil compaction but soil compaction depends on a lot of parameters and considering each parameter is difficult for heterogeneous structures of the soil. Modelling of the effects of the soil compaction on the environment and plant growth are reviewed and discussed in detail in literature (Clausnitzer and Hopmans 1994; Grant 1993; O'Sullivan and Simota 1995). Several attempts have been made to model the effects of mechanical operations on the soil (Blackwell and Soane 1981; Défossez and Richard 2002; Dickson and Ritchie 1993; Raper and Erbach 1990), but most models have limited applications due to a large number of parameters as input or heterogeneous field conditions. Models can also be classified and discussed as mechanistic or empirical, depending on the treatment of underlying mechanisms, and deterministic or stochastic, depending on the treatment of variability (O’Sullivan and Simota 1995).

\subsection{Stress-strain models based upon boussinesq equation}

Most of the models are based on the stress-strain theory where two problems are addressed:

- The propagation of stress in the soil

- The local relation between stress and strain i.e.; the "constitutive equation"

The propagation of stress in the soil is classically described by some form of the Boussinesq equation (Boussinesq 1885, p. 104), and a constant linear relation between stress and strain is assumed, that is, soil reacts elastically. The form of the Boussinesq equation depends on the limiting condition. For a point load (Fig. 8), it is:

$\sigma_{Z}=\left(3 P / 2 \pi r^{2}\right) \cos ^{3} \theta$

where, $r$ is the radial distance from point $A$ to the origin $O$ where the load $P$ is applied, and $\theta$ is the angle between $O A$ and the vertical, $\sigma_{Z}$ is the vertical stress.

In this equation, time is absent, and, therefore, it describes the situation at mechanical equilibrium in static conditions. Moreover, as underlined by Smith et al. (2000), the stress 


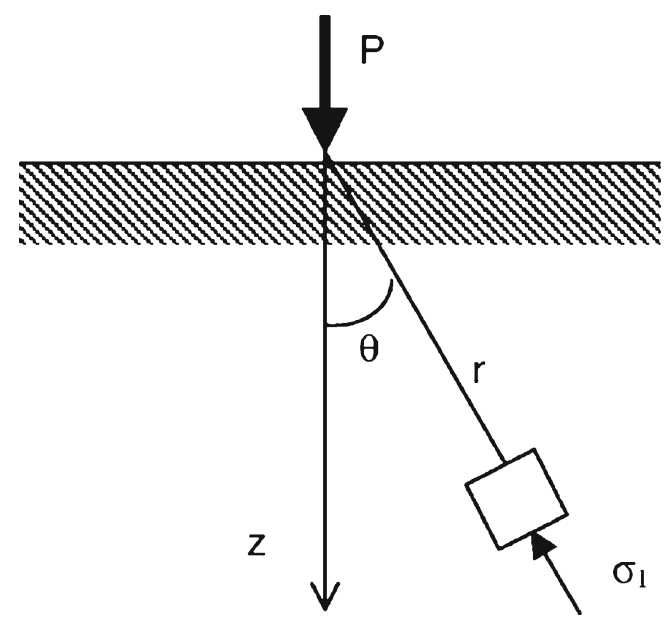

Fig. 8 Stress propagation to a layer parallel to the surface at depth $z$ for a homogeneous isotropic soil, under the assumption of elasticity, in a soil submitted to a point load $P$ exerting a normal stress at the surface. From Défossez and Richard (2002)

distribution is "irrespective of differences in texture, bulk density or water content". To better describe the stress distribution, the "concentration factor", $v$ was introduced by Fröhlich (1934; quoted by Défossez and Richard 2002), so that the equation becomes:

$\sigma_{\mathrm{Z}}=\left(v \mathrm{P} / 2 \pi \mathrm{r}^{2}\right) \cos ^{\mathrm{v}} \theta$

which means that, when compared to Eq. 1, the geometric coefficient 3 is treated as an adjustable parameter. When the "concentration factor" increases, stress increases at a given point. Söhne (1958; quoted by Défossez and Richard 2002) suggested $n$ values of 4, 5, and 6 for hard, firm and soft soil respectively, and Défossez and Richard (2002) commented as: "The firmness results from empirical combinations of both the bulk density and water status of the soil." According to Smith et al. (2000), the concentration factor can even obtain values of 6-9, and is influenced by the soil structure: "in well-aggregated soils, the concentration factor values are smaller than in the same but homogenized soils." They used even values smaller than $3(v=1)$, in simulations, and calculated values from 1.5 to 2.8 for different decreasing laws of the tire load from just below the tire centre to its external limit.

Analytical models based upon Boussinesq equation and on its modifications are largely used as they demand less number of inputs as compared to models based on the finite element method (FEM). The comparison with experiments largely gives variable results, acceptable for homogeneous soils and unreliable for heterogeneous soils due to the presence of clods or a firm soil at depth (Défossez and Richard 2002). In homogeneous soils, they can predict efficiently not only soil stress-strain behaviour but also the propagation of the loading forces within the soil resulting from forces applied at the soil surface from farm vehicles.
A recent analytical model is SoilFlex, easily usable, is based upon a description of the upper boundary condition (load of tyre) as an ellipse or a super ellipse, considering both normal and shear stresses, an analytical solution to compute the stress propagation and a calculation of the soil deformation (Keller et al. 2007; Keller and Lamandé 2010). According to Keller et al. (2007), "A weak point of the analytical solution may be the concentration factor, as it is not a directly measurable soil parameter."

According to Smith et al. (2000), the concentration factor fitted "can result in inaccurate results if they are used for comparing strength among different soils [....], and it is a machinery-soil dependent parameter, [influenced by] inflation pressure, tires dimensions, lugs and carcass stiffness". These latter authors concluded that "Boussinesq's equations, modified by concentration factors and elliptic coordinates failed to predict experimental stress values in a Hapludand."

In addition, the Boussinesq equation and its classical modifications are restricted to a boundary condition of normal stress while Boussinesq proposed other integrals applicable to tangential forces which due to the linearity of the differential operators can be combined to give general solutions for any external stresses; the solutions are derived from potentials that are: (1) ordinary, $\int(\mathrm{dm} / \mathrm{r})$, when displacements are known at the boundary surface; (2) logarithmic $\int \ln (z+r) \mathrm{dm}$, when normal stresses are known; (3) logarithmic $\int[-r+z \ln (z+r)] \mathrm{dm}$, when stresses at the surface are purely tangential (Boussinesq 1885, p. 201).

The major problem with Boussinesq's theory is that it is restricted to elastic domain which implies that there is no permanent deformation and no rupture and the solid is supposed to be homogeneous and isotropic. Moreover, it does not represent accurately hydraulic properties of the soil and cannot describe the soil deformation. Furthermore, these methods fail to predict changes at pore-scale level (Or and Ghezzehei 2002).

\subsection{Virtual work formulation}

A different way of computing the propagation of stress is based upon a local description of the virtual work:

$$
\int \delta \underline{\varepsilon}^{T} \underline{\sigma} d V=\int \delta \underline{u}^{T} \underline{p} d V+\oint \delta \underline{u}^{T} \underline{t} d A
$$

where, $V$ and $A$ are the volume and the area of the surface of the deformed body, $\underline{\sigma}$ and $\underline{\varepsilon}$ the tensors of stress and strain, $\delta \underline{u}$ is the incremental displacement, $\underline{p}$ and $\underline{t}$ are respectively the body forces and surface traction, and the superscript $T$ stands for transformed (Défossez and Richard 2002).

Time is equally absent from the equation and it describes static deformation of a soil body. This equation is then linearized which assumes low deformation and numerically 
solved, using finite element methods. The corresponding models are referred to as FEM. These models are adequate for modelling the 3D distribution of stress within the soil induced by wheeling and the complex stress-strain behaviour of the soil but due to continuous changes of elastic parameters of the soil, application of FEM models becomes limited (Raper and Erbach 1990).

Whether the stress propagation is computed by a pseudo-analytical procedure (Boussinesq and its variants) or by FEM, it fails to account for two evidences: the existence of preferential paths of stress propagation and the localization of deformation (hard pans, plough pans...). These items will be addressed in the following paragraphs.

\subsection{Preferential paths of stress propagation}

Stresses do not often propagate homogeneously but through preferential paths, isolating bulk volumes that are not under so large stress as it is in the preferential path. This is due to the fact that in soils, there coexist different assemblages due to small differences between the size and shape of the particles. When submitted to a compression, the soil particles or grains will tend to move at first elastically. Soon, some of these grains will be blocked ("jammed") against each other and normal stresses will be transmitted along chains of preferential propagation. When these chains constitute a continuous path, by a percolation process (Bideau and Hansen 1993; Guyon and Troadec 1994; Roux et al. 1993), they will isolate bulk volumes submitted to smaller stress or even free to move (Fig. 9).
There have been advances in physics of granular media, due to both fundamental interest for physicists as models of much more complex systems and to practical and/or industrial interest: "granular materials are ubiquitous in nature and are the second most manipulated material in industry (the first one is water)" (Richard et al. 2005). One of the main characteristics of granular materials is that their behaviour is intermediate between solids and fluids. Compaction from a loosepacked material can be efficiently obtained by tapping and shearing, and this is more efficient than compression. Granular packings submitted to gentle mechanical taps can reach a stationary configuration which does not depend on the initial conditions (looser packing or denser packing; Ribière et al. 2007). As friction between solid particles oppose to mixing and thermal agitation is entirely negligible with respect to potential energy due to gravitation $\left(>1 \times 10^{12} \mathrm{kT}\right)$, solid particles can segregate which is well-known in soils, though at first sight, it could be considered as violating the natural tendency for entropy to increase. Those materials are, thus, considered as "a-thermal" and metastable assemblages can persist as long as no perturbation occurs (Jaeger et al. 1996). This metastability of different assemblages explains in a large part soil heterogeneity. Forces in such materials at rest appear to be very heterogeneous, forming chains along which stresses are very intense (Majmudar and Behringer 2005). Those chains isolate volumes which are not under stress forming arches, as is well-known in silos. This behaviour is strongly influenced by the shape and rugosity of particles. When compression proceeds further, deformation can be localized in specific locations.
Fig. 9 Preferential paths of stress propagation. From Majmudar and Behringer (2005): comparison of experimental images $(\mathbf{a}, \mathbf{c})$ and computed images $(\mathbf{b}, \mathbf{d})$.Top pair a low-force sheared state. Bottom pair a high-stress isotropically compressed state
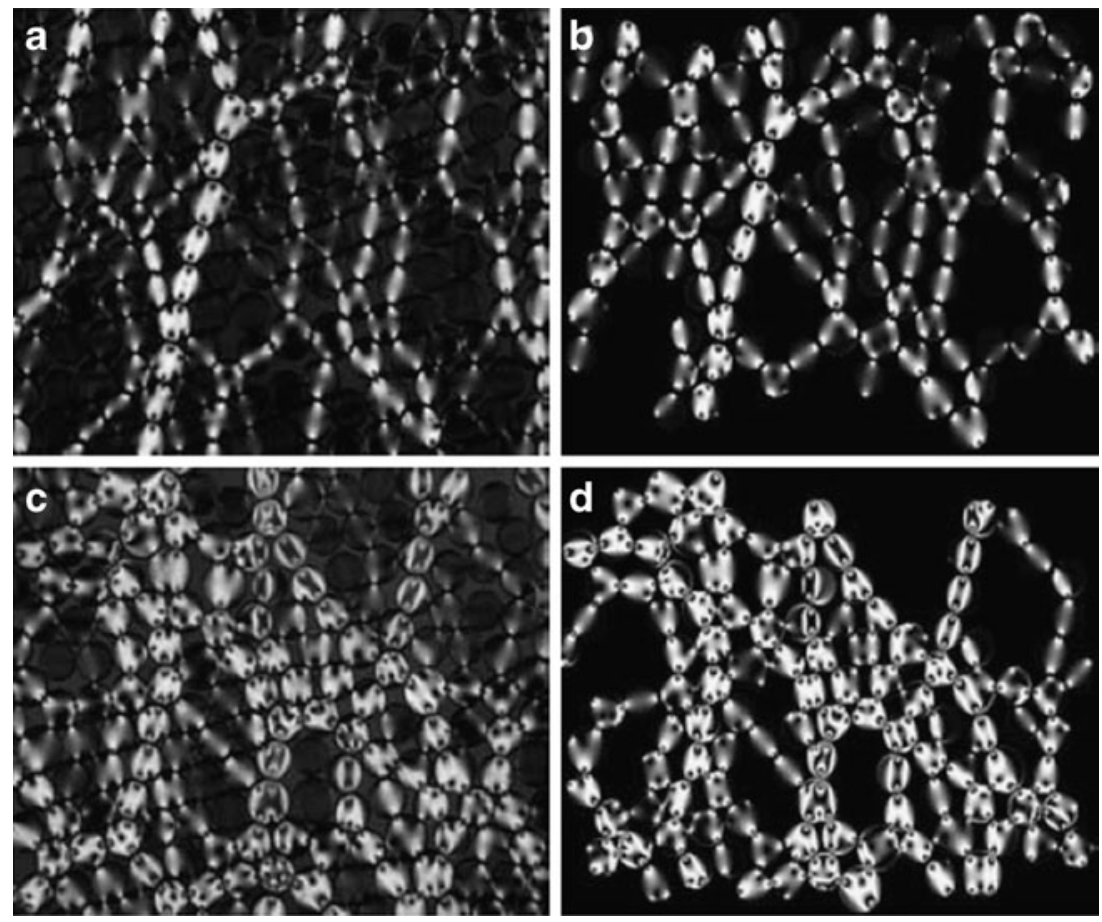


\subsection{Strain localization}

There exists a broad evidence that strain is not evenly distributed in soils, rocks, and geomaterials such as concrete. Indeed, strain localization is rather a rule. It is generally associated with plastic deformation and ruptures in solids and is observed to concentrate in narrow zones, called shear bands (Desrues and Chambon 2002). Such localized deformations have been observed in many granular materials, from sand (Desrues and Viggiani 2004) to clays, e.g., by X-ray tomography (Bésuelle et al. 2007; Fig. 10).

The material undergoes a transition from a diffused strain mode to a localized strain mode where strain is strongly spatially concentrated while the material outside this zone behaves approximately as rigid (Bésuelle et al. 2007). In soils, this is the case for example in hard pans. And, at a much larger scale, this is the basic paradigm of plate tectonics. This feature seems, thus, very general. Looking back at Boussinesq Eq. 1, equation structure precludes the existence of a maximum in stress and strain at a specific location as second derivative of this equation is always positive. It is interesting to note that the presence of an inclusion, whether weaker or stronger than the bulk material, dictates the location of the shear band (Desrues and Viggiani 2004). Chambon et al. (1994, 2000) proposed a constitutive model based upon a stress rate/strain rate relationship instead of a stress/strain relationship. It is a continuous model like the aforementioned models which means that the distances considered are much larger than the grain size and is called CLoE, formed on the words consistency and explicit localization. Failure is accounted for by incorporating explicitly a limit surface in stress space separating admissible states from inaccessible states. The constitutive equation is:

$$
\dot{\sigma}=A: \dot{\varepsilon}+b\|\dot{\varepsilon}\|
$$

where, $\sigma$ is the stress rate, $\dot{\varepsilon}$ the strain rate, $A$ is a fourth-rank tensor and "b" a second-order tensor; the incremental no-linearity is due to the norm $\|\dot{\varepsilon}\| ; \dot{\varepsilon}$ is not decomposed into elastic and plastic parts. $A$ and $b$ depend on state variables and are determined by an interpolation procedure between the responses for axisymmetric triaxial states. The formation of a shear band is treated in model CLoE as a bifurcation problem. The appropriate 16 parameters for a given material are derived from simple axisymmetric triaxial compression and extension tests except out-ofaxes shear moduli which are derived from special experimental tests combined with inverse analysis (Desrues and Chambon 2002).

Time is, thus, present in this model and this accounts for the fact that the rate of stress is a parameter of a paramount importance. The discrepancies between laboratory tests and field wheeling experiments have been ascribed to the differences in loading time (Keller and Lamandé 2010). In the soils, the localization of strain in shear bands separated by volumes behaving as more rigid can explain the observation of discrepancies when modelling the soils with clods or with an underlying dense layer at depths less than $0.5 \mathrm{~m}$ (Défossez and Richard 2002).

Boussinesq equations and FEM models are restricted to elastic domain and fail to take account of existence of preferential paths of stress propagation and localization of deformation in compacted soils. Modified forms of a constitutive model like CLoE that is based upon a stress rate/strain rate relationship in granular media can be able to decrease discrepancies in modelling the soil compaction when there is localised soil deformation.

\section{Remedies to the soil compaction}

Natural phenomena involved in the recovery of compacted soils are precipitations, wetting and drying cycles, subsequent soil cracking, freeze-thaw cycles, and bioturbation which includes earthworm burrowing and root penetration and decay (Drewry 2006; Webb 2002). Natural recovery of compacted soil is a very complex and slow process that can take at average from 5 to 18 years depending on the soil type, degree of compaction, and climate (Froehlich et al. 1985).
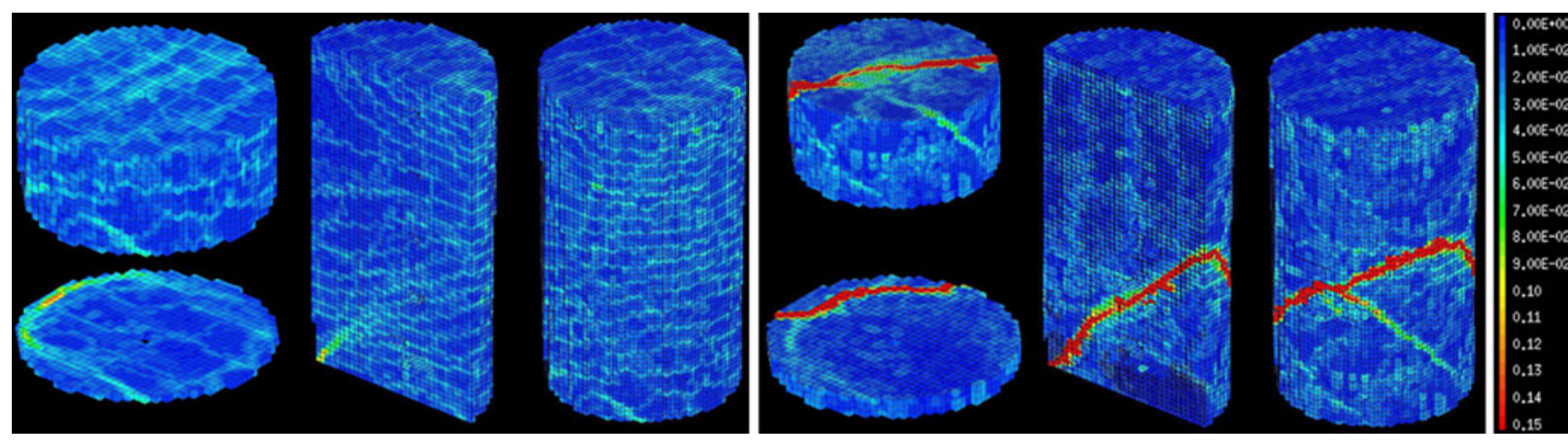

Fig. 10 Strain localization in shear bands. From Bésuelle et al. (2007). Left initialization of the shear band. Right development of the shear band 
Among all the aforementioned factors, the degree of compaction or bulk density is the most important factor to monitor the recovery time of a soil (Heinonen 1977). If the soils are not highly compacted, repetitions of alternative dry and wet periods can reduce the soil compaction in the clay soils but the sandy compacted soils are less affected by these natural restoration cycles. Rapid natural amelioration of physically deteriorated topsoil to about $5 \mathrm{~cm}$ is possible but below $15 \mathrm{~cm}$ natural rejuvenated process is very slow (Drewry 2006). For example, full recovery time for a heavy compacted soil can range from 100 to 190 years (Webb 2002).

Compaction can be reduced by the natural methods through increase of vegetation and addition of organic matter by preventive measures through controlling traffic and animal load or by mechanical methods by deep ripping (Berg 1975) and disking (Dickerson 1976). Aforementioned solutions have been reviewed in farm systems (Hamza and Anderson 2005). In the forests, any mechanical work to reduce the soil compaction is difficult due to presence of stumps and large roots, so, natural methods are encouraged and employed.

\section{Conclusion}

Soil productivity is very important for human survival but any form of soil degradation can reduce the soil fertility and ultimately, it lowers the soil productivity. The soil compaction, a physical form of soil degradation, is a worldwide problem that has resulted in the yield reductions of agronomic crops and reduced growth rate of forests. It has attracted scientists' attention for more than a century, both on the practical and theoretical aspects. Experimental studies have shown that the soil compaction results in increase in the soil strength, bulk density, volumetric water contents, and field capacity while decrease in total porosity, soil aeration, water infiltration rate, and saturated hydraulic conductivity. Causes of the soil compaction identified are natural (rainfall, plant roots, foot traffic of man, or animal) or artificial (mechanical operations).

Several models, nowadays, are available to not only assess the soil compaction due to traffic load but also to calculate the negative effects of the soil compaction on different compartments of the soil, plant, and environment. However, until now, there is no unique model for all types of soils and climates. Classical engineers' approach derived from Boussinesq equation by introducing an empirical "concentration factor" fails to account for the experimental results as soon as the soil is heterogeneous; the stress applied exceeds the elasticity limit. Moreover, the assumption of a normal stress is not valid as soon as tangential stresses are present at the boundary limit (soil surface) while more general solutions were given by Boussinesq himself.

Virtual work equation, solved by FEM, is more satisfactory but requires many more parameters. Recent advances in physics of granular materials are promising but until now restricted to very simple systems. A link between those two approaches is, in principle, possible and is indeed the need of the time. Many recent reviews suggest that the future research should focus more on dynamics of loading and the data acquired could be treated with dynamic models, such as CLoE, relating stress rate and strain rate.

The soil compaction is rapid and easy due to mechanisation, but it takes years to restore a compacted soil. In spite of hundreds of articles appearing during the last 10 years on the soil compaction, there is an urgent need to apply multidisciplinary approach in the soil compaction studies, addressing diverse effects in different soil compartments (Fig. 2). Progress in sensors in both the soil physics and soil chemistry and in data treatment should be of a great help to evaluate the effects of the soil compaction on every compartment of the biogeosphere.

Acknowledgments The support of the Higher Education Commission (HEC) of Pakistan and the Société Française d'Exportation des Ressources Éducatives (SFERE) for the grant for MF Nawaz are gratefully acknowledged. Pr. D. Bideau and Dr P. Défossez are greatly thanked for fruitful discussions.

Open Access This article is distributed under the terms of the Creative Commons Attribution Noncommercial License which permits any noncommercial use, distribution, and reproduction in any medium, provided the original author(s) and source are credited.

\section{References}

Alakukku L, Weisskopf P, Chamen W, Tijink F, Van Der Linden J, Pires S, Sommer C, Spoor G (2003) Prevention strategies for field traffic-induced subsoil compaction: a review. Part 1. Machine/soil interactions. Soil Till Res 73:145-160

Alameda D, Villar R (2009) Moderate soil compaction: implications on growth and architecture in seedlings of 17 woody plant species. Soil Till Res 103:325-331

Alletto L, Coquet Y, Benoit P, Heddadj D, Barriuso E (2010) Tillage management effects on pesticide fate in soils. A review. Agron Sustain Dev 30:367-400

Arah J, Smith K (1989) Steady-state denitrification in aggregated soils: a mathematical model. Eur J Soil Sci 40:139-149

Arvidsson J (1999) Nutrient uptake and growth of barley as affected by soil compaction. Plant Soil 208:9-19

Bakker D, Davis R (1995) Soil deformation observations in a Vertisol under field traffic. Aust J Soil Res 33:817-832

Ball B, Scott A, Parker J (1999) Field $\mathrm{N}_{2} \mathrm{O}, \mathrm{CO}_{2}$ and $\mathrm{CH}_{4}$ fluxes in relation to tillage, compaction and soil quality in Scotland. Soil Till Res 53:29-39

Batey T (2009) Soil compaction and soil management-a review. Soil Use Manage 25:335-345

Berg P (1975) Developments in the establishment of second rotation radiata pine at Riverhead Forest. New Zeal J For Sci 20:272-282

Bessou C, Mary B, Léonard J, Roussel M, Gréhan E, Gabrielle B (2010) Modelling soil compaction impacts on nitrous oxide emissions in arable fields. Eur J Soil Sci 61:348-363

Bésuelle P, Desrues J, Viggiani G, Lenoir N (2007) Caractérisation expérimentale de la déformation et de la rupture localisée dans 
une argilite. 18e Congrès français de mécanique, Grenoble, 27-31 Août 2007. AFM, Maison de la Mécanique, Courbevoie, pp 1-6

Beylich A, Oberholzer H, Schrader S, Höper H, Wilke B (2010) Evaluation of soil compaction effects on soil biota and soil biological processes in soils. Soil Till Res 109:133-143

Bhandral R, Saggar S, Bolan N, Hedley M (2007) Transformation of nitrogen and nitrous oxide emission from grassland soils as affected by compaction. Soil Till Res 94:482-492

Bideau D, Hansen A (1993) Disorder and granular media. Elsevier, New York, p 323

Blackwell P, Soane B (1981) A method of predicting bulk density changes in field soils resulting from compaction by agricultural traffic. Eur J Soil Sci 32:51-65

Botta G, Jorajuria D, Rosatto H, Ferrero C (2006) Light tractor traffic frequency on soil compaction in the Rolling Pampa region of Argentina. Soil Till Res 86:9-14

Boussinesq J (1885) Application des potentiels à l'étude de l'équilibre et du mouvement des solides élastiques, principalement au calcul des déformations et des pressions que produisent, dans ces solides, des efforts quelconques exercés sur une petite partie de leur surface ou de leur intérieur; mémoire suivi de notes étendues sur divers points de physique mathématique et d'analyse. Gauthier-Villars, Paris, $\mathrm{p} 722$

Bouwman L, Arts W (2000) Effects of soil compaction on the relationships between nematodes, grass production and soil physical properties. Appl Soil Ecol 14:213-222

Bruand A, Cousin I, Nicoullaud B, Duval O, Begon J (1996) Backscattered electron scanning images of soil porosity for analyzing soil compaction around roots. Soil Sci Soc Am J 60:895-901

Buck C, Langmaack M, Schrader S (2000) Influence of mulch and soil compaction on earthworm cast properties. Appl Soil Ecol 14:223229

Cannell R (1977) Soil aeration and compaction in relation to root growth and soil management. Appl Biol 2:1-86

Chambon R, Desrues J, Hammad W (1994) CLoE, a new rate-type constitutive model for geomaterials theoretical basis and implementation. Int J Numer Anal Met 18:253-278

Chan K, Barchia I (2007) Soil compaction controls the abundance, biomass and distribution of earthworms in a single dairy farm in south-eastern Australia. Soil Till Res 94:75-82

Charpentier S, Bourrié G (1997) Deformation of saturated clays under mechanical and osmotic stress and its relation with the arrangement of the clays. Eur J Soil Sci 48:49-57

Clausnitzer V, Hopmans J (1994) Simultaneous modeling of transient three dimensional root growth and soil water flow. Plant Soil 164:299-314

Clayton H, Arah J, Smith K (1994) Measurement of nitrous oxide emissions from fertilized grassland using closed chambers. J Geophys Res-Atmos 99:16599-16607

Conlin T, Van den Driessche R (2000) Response of soil $\mathrm{CO}_{2}$ and $\mathrm{O}_{2}$ concentrations to forest soil compaction at the long-term soil productivity sites in central British Columbia. Can J Soil Sci 80:625-632

Corns I (1988) Compaction by forestry equipment and effects on coniferous seedling growth on four soils in the Alberta foothills. Can J Forest Res 18:79-88

Cui K, Défossez P, Cui YJ, Richard G (2010) Soil compaction by wheeling: changes in soil suction caused by compression. Eur J Soil Sci 61:599-608

Davidson E, Swank W, Perry T (1986) Distinguishing between nitrification and denitrification as sources of gaseous nitrogen production in soil. Appl Environ Microb 52:1280-1286

De Neve S, Hofman G (2000) Influence of soil compaction on carbon and nitrogen mineralization of soil organic matter and crop residues. Biol Fert Soils 30:544-549

Défossez P, Richard G (2002) Models of soil compaction due to traffic and their evaluation. Soil Till Res 67:41-64
Demir M, Makineci E, Gungor B (2008) Plant species recovery on a compacted skid road. Sensors 8:3123-3133

Desrues J, Chambon R (2002) Shear band analysis and shear moduli calibration. Int J Solids Struct 39:3757-3776

Desrues J, Viggiani G (2004) Strain localization in sand: an overview of the experimental results obtained in Grenoble using sterophotogrammetry. Int J Numer Anal Met 28:279-321

Dexter A (1978) Tunnelling in soil by earthworms. Soil Biol Biochem 10:447-449

Dexter A (1987) Compression of soil around roots. Plant Soil 97:401406

Dick R, Myrold D, Kerle E (1988) Microbial biomass and soil enzyme activities in compacted and rehabilitated skid trail soils. Soil Sci Soc Am J 52:512-516

Dickerson B (1976) Soil compaction after tree-length skidding in northern Mississippi. Soil Sci Soc Am J 40:965-966

Dickson J, Ritchie R (1993) Soil and crop responses to zero, reduced ground pressure and conventional traffic systems in an arable rotation on a clay loam, 1991. Departmental Note-Scottish Centre of Agricultural Engineering (UK)

Dolan M, Dowdy R, Voorhees W, Johnson J, Bidwell-Schrader A (1992) Corn phosphorus and potassium uptake in response to soil compaction. Agron J 84:639-642

Douglas J, Crawford C (1991) Wheel-induced soil compaction effects on ryegrass production and nitrogen uptake. Grass Forage Sci 46:405-416

Douglas J, Crawford C (1993) The response of a ryegrass sward to wheel traffic and applied nitrogen. Grass Forage Sci 48:91-100

Drewry J (2006) Natural recovery of soil physical properties from treading damage of pastoral soils in New Zealand and Australia: a review. Agr Ecosyst Environ 114:159-169

Drewry J, Cameron K, Buchan G (2008) Pasture yield and soil physical property responses to soil compaction from treading and grazing - a review. Aust J Soil Res 46:237-256

Durán Zuazo VH, Rodríguez Pleguezuelo CR (2008) Soil-erosion and runoff prevention by plant covers. A review. Agron Sustain Dev 28:65-86

Dürr C, Aubertot J (2000) Emergence of seedlings of sugar beet (Beta vulgaris L.) as affected by the size, roughness and position of aggregates in the seedbed. Plant Soil 219:211-220

Eguchi T, Muro T (2007) Measurement of compacted soil density in a compaction of thick finishing layer. J Terramechanics 44:347-353

Eswaran H, Lal R, Reich P (2001) Land degradation: an overview. In: Bridges E, Hannam I, Oldeman L, de Vries PF, Scherr S, Sompatpanit $\mathrm{S}$ (eds) Responses to land degradation. Oxford Press, New Delhi, pp 20-35

Fabiola N, Giarola B, da Silva A, Imhoff S, Dexter A (2003) Contribution of natural soil compaction on hardsetting behavior. Geoderma 113:95-108

Feder F, Trolard F, Klingelhöfer G, Bourrié G (2005) In situ Mössbauer spectroscopy - evidence for green rust (Fougerite) in a gleysol and its mineralogical transformations with time and depth. Geochim Cosmochim Ac 69:4463-4483

Flowers M, Lal R (1998) Axle load and tillage effects on soil physical properties and soybean grain yield on a mollic ochraqualf in northwest Ohio. Soil Till Res 48:21-35

Frey B, Kremer J, Rüdt A, Sciacca S, Matthies D, Lüscher P (2009) Compaction of forest soils with heavy logging machinery affects soil bacterial community structure. Eur J Soil Biol 45:312-320

Frick J, Degenhardt B, Buchecker M (2007) Predicting local residents' use of nearby outdoor recreation areas through quality perceptions and recreational expectations. For Snow Landsc Res 81:31-41

Fritz V, Allmaras R, Pfleger F, Davis D (1995) Oat residue and soil compaction influences on common root rot (Aphanomyes euteiches) of peas in a fine-textured soil. Plant Soil 171:235244 
Froehlich H, Miles D, Robbins R (1985) Soil bulk density recovery on compacted skid trails in central Idaho. Soil Sci Soc Am J 49:10151017

Fröhlich OK (1934) Druckverteilung im Baugrunde (pressure distribution in soil foundation). Springer, Wien, p 178

Gerard C, Sexton P, Shaw G (1982) Physical factors influencing soil strength and root growth. Agron J 74:875-879

Gilliam F (2007) The ecological significance of the herbaceous layer in temperate forest ecosystems. Bioscience 57:845-858

Glinski J, Lipiec J (1990) Soil physical conditions and plant roots. CRC Press, Boca Raton

Grant R (1993) Simulation model of soil compaction and root growth. Plant Soil 150:1-14

Greacen E, Sands R (1980) Compaction of forest soils. A review. Aust J Soil Res 18:163-189

Greene W, Stuart W (1985) Skidder and tire size effects on soil compaction. South J Appl For 9:154-157

Gupta S, Sharma P, Defranchi S (1989) Compaction effects on soil structure1. Adv Agron 42:311-338

Guyon É, Troadec JP (1994) Du sac de billes au tas de sable. Éditions Odile Jacob, Paris, p 306p

Gysi M, Ott A, Flühler H (1999) Influence of single passes with high wheel load on a structured, unploughed sandy loam soil. Soil Till Res 52:141-151

Håkansson I (1990) A method for characterizing the state of compactness of the plough layer. Soil Till Res 16:105-120

Håkansson I, Lipiec J (2000) A review of the usefulness of relative bulk density values in studies of soil structure and compaction. Soil Till Res 53:71-85

Hamza M, Anderson W (2003) Responses of soil properties and grain yields to deep ripping and gypsum application in a compacted loamy sand soil contrasted with a sandy clay loam soil in Western Australia. Aust J Agr Res 54:273-282

Hamza M, Anderson W (2005) Soil compaction in cropping systems A review of the nature, causes and possible solutions. Soil Till Res $82: 121-145$

Heinonen R (1977) Towards "normal" soil bulk density. Soil Sci Soc Am J 41:1214-1215

Hemmat A, Adamchuk V (2008) Sensor systems for measuring soil compaction: review and analysis. Comput Electron Agr 63:89103

Herbauts J, El Bayad J, Gruber W (1996) Influence of logging traffic on the hydromorphic degradation of acid forest soils developed on loessic loam in middle Belgium. Forest Ecol Manag 87:193207

Hillel D (2009) The mission of soil science in a changing world. J Plant Nutr Soil Sci 172:5-9

Horn R (1988) Compressibility of arable land. Catena Supp 11:53-71

Horn R, Rostek J (2000) Subsoil compaction processes-state of knowledge. Adv Geoecol 32:4-54

Horn R, Doma H, Sowiska-Jurkiewicz A, Van Ouwerkerk C (1995) Soil compaction processes and their effects on the structure of arable soils and the environment. Soil Till Res 35:23-36

Ishaq M, Hassan A, Saeed M, Ibrahim M, Lal R (2001) Subsoil compaction effects on crops in Punjab. Pakistan I. Soil physical properties and crop yield. Soil Till Res 59:57-65

Jaeger HM, Nagel SR, Behringer RP (1996) The physics of granular materials. Phys Today 49(4):32-38

Jim C (1987) Trampling impacts of recreationists on picnic sites in a Hong Kong country park. Environ Conserv 14:117-127

Jones R, Spoor G, Thomasson A (2003) Vulnerability of subsoils in Europe to compaction: a preliminary analysis. Soil Till Res 73:131143

Jones A, Stolbovoy V, Rusco E, Gentile AR, Gardi C, Marechal B, Montanarella L (2009) Climate change in Europe. 2. Impact on soil. A review. Agron Sustain Dev 29:423-432
Jordan D, Ponder F, Hubbard V (2003) Effects of soil compaction, forest leaf litter and nitrogen fertilizer on two oak species and microbial activity. Appl Soil Ecol 23:33-41

Keller T, Lamandé M (2010) Challenges in the development of analytical soil compaction models. Soil Till Res 111:54-64

Keller T, Défossez P, Weisskopf P, Arvidsson J, Richard G (2007) SoilFlex: a model for prediction of soil stresses and soil compaction due to agricultural field traffic including a synthesis of analytical approaches. Soil Till Res 93:391-411

Kirby J, Bengough A (2002) Influence of soil strength on root growth: experiments and analysis using a critical-state model. Eur J Soil Sci 53:119-127

Kirby J, Blunden B, Trein C (1997) Simulating soil deformation using a criticalstate model: II. Soil compaction beneath tyres and tracks. Eur J Soil Sci 48:59-70

Kissling M, Hegetschweiler K, Rusterholz H, Baur B (2009) Shortterm and long-term effects of human trampling on above-ground vegetation, soil density, soil organic matter and soil microbial processes in suburban beech forests. Appl Soil Ecol 42:303-314

Kosmas C, Danalatos N, Cammeraat L, Chabart M, Diamantopoulos J, Farand R, Gutierrez L, Jacob A, Marques H, Martinez-Fernandez J (1997) The effect of land use on runoff and soil erosion rates under Mediterranean conditions. Catena 29:45-59

Kretzschmar A (1991) Burrowing ability of the earthworm Aporrectodea longa limited by soil compaction and water potential. Biol Fert Soils $11: 48-51$

Kristoffersen A, Riley H (2005) Effects of soil compaction and moisture regime on the root and shoot growth and phosphorus uptake of barley plants growing on soils with varying phosphorus status. Nutr Cycl Agroecosys 72:135-146

Lal R (2009) Soils and food sufficiency, a review. Agron Sustain Dev 29:113-133

Lipiec J, Hatano R (2003) Quantification of compaction effects on soil physical properties and crop growth. Geoderma 116:107-136

Lipiec J, Stepniewski W (1995) Effects of soil compaction and tillage systems on uptake and losses of nutrients. Soil Till Res 35:37-52

Loghavi M, Khadem M (2006) Development of a soil bin compaction profile sensor. J Agr Sci 8:1-13

Lowery B, Schuler R (1991) Temporal effects of subsoil compaction on soil strength and plant growth. Soil Sci Soc Am J 55:216233

Maag M, Vinther F (1996) Nitrous oxide emission by nitrification and denitrification in different soil types and at different soil moisture contents and temperatures. Appl Soil Ecol 4:5-14

Majmudar TS, Behringer RP (2005) Contact force measurements and stress induced anisotropy in granular materials. Nature 435 (23): 1079-1082

Marion J, Cole D (1996) Spatial and temporal variation in soil and vegetation impacts on campsites. Ecol Appl 6:520-530

Marschner H (1986) Mineral nutrition of higher plants. Academic, London

Masle J, Passioura J (1987) The effect of soil strength on the growth of young wheat plants. Australian J Plant Physiol 14:643-656

Materechera S, Mloza-Banda H (1997) Soil penetration resistance, root growth and yield of maize as influenced by tillage system on ridges in Malawi. Soil Till Res 41:13-24

Materechera S, Dexter A, Alston A (1991) Penetration of very strong soils by seedling roots of different plant species. Plant Soil 135:3141

McGarry D, Sharp G (2003) A rapid, immediate, farmer-usable method of assessing soil structure condition to support conservation agriculture. Conservation agriculture: environment, farmers experiences, innovations, socio-economy, policy, p. 375

Medvedev V, Cybulko W (1995) Soil criteria for assessing the maximum permissible ground pressure of agricultural vehicles on Chernozem soils. Soil Till Res 36:153-164 
Moehring D, Rawls I (1970) Detrimental effects of wet weather logging. J Forest 68:166-167

Mosaddeghi M, Hajabbasi M, Hemmat A, Afyuni M (2000) Soil compactibility as affected by soil moisture content and farmyard manure in central Iran. Soil Till Res 55:87-97

Mueller L, Schindler U, Mirschel W, Shepherd TG, Ball BC, Helming K, Rogasik J, Eulenstein F, Wiggering H (2010) Assessing the productivity function of soils. A review. Agron Sustain Dev 30:601-614

Munch J, Ottow J (1983) Reductive transformation mechanism of ferric oxides in hydromorphic soils. Ecol Bull 35:383-394

Nawaz MF (2010) Geochemistry of hydromorphic soils and waters under rice culture and forest - continuous measurements, thermodynamic modelling and kinetics. Thesis, Marseille University, 211p

O'Sullivan M, Simota C (1995) Modelling the environmental impacts of soil compaction: a review. Soil Till Res 35:69-84

Ohu J, Folorunso O, Adeniji F, Raghavan G (1989) Critical moisture content as an index of compactibility of agricultural soils in Borno State of Nigeria. Soil Technol 2:211-219

Or D, Ghezzehei T (2002) Modeling post-tillage soil structural dynamics: a review. Soil Till Res 64:41-59

Panayiotopoulos K, Papadopoulou C, Hatjiioannidou A (1994) Compaction and penetration resistance of an Alfisol and Entisol and their influence on root growth of maize seedlings. Soil Till Res 31:323-337

Petersen H, Luxton M (1982) A comparative analysis of soil fauna populations and their role in decomposition processes. Oikos 39:288-388

Piñeiro G, Paruelo J, Oesterheld M, Jobbágy E (2010) Pathways of grazing effects on soil organic carbon and nitrogen. Rangeland Ecol Manag 63:109-119

Ponnamperuma F (1985) Chemical kinetics of wetland rice soils relative to soil fertility. In: Wetland soils, characterization, classification and utilization. Agribookstore, Philippine, p 71

Pupin B, Freddi O, Nahas E (2009) Microbial alterations of the soil influenced by induced compaction. Rev Bras Cienc Solo 33:12071213

Quiroga A, Buschiazzo D, Peinemann N (1999) Soil compaction is related to management practices in the semi-arid Argentine pampas. Soil Till Res 52:21-28

Radford B, Bridge B, Davis R, McGarry D, Pillai U, Rickman J, Walsh P, Yule D (2000) Changes in the properties of a Vertisol and responses of wheat after compaction with harvester traffic. Soil Till Res 54:155-170

Radford B, Wilson-Rummenie A, Simpson G, Bell K, Ferguson M (2001) Compacted soil affects soil macrofauna populations in a semi-arid environment in central Queensland. Soil Biol Biochem 33:1869-1872

Raper R, Erbach D (1990) Prediction of soil stresses using the finite element method. T Am Soc Agr Eng (USA) 33:725-730

Renault P, Stengel P (1994) Modeling oxygen diffusion in aggregated soils: I. Anaerobiosis inside the aggregates. Soil Sci Soc Am J 58:1017-1023

Ribière P, Richard P, Philippe P, Bideau D, Delannay R (2007) On the existence of stationary stated during granular compaction. Eur Phys J 22:249-253

Richard P, Nicodemi M, Delannay R, Ribière P, Bideau D (2005) Slow relaxation and compaction of granular systems. Nat Mater 4:121-128

Rosolem C, Foloni J, Tiritan C (2002) Root growth and nutrient accumulation in cover crops as affected by soil compaction. Soil Till Res 65:109-115

Roux S, Bideau D, Hansen A (1993) Properties of the grain space of packings: effects of heterogeneities. In: Bideau D and Hansen A (eds) Disorder and granular media. Chapter 8. pp. 229-254

Sakai H, Nordfjell T, Suadicani K, Talbot B, Bøllehuus E (2008) Soil compaction on forest soils from different kinds of tires and tracks and possibility of accurate estimate. Croat J For Eng 29:15-27
Saqib M, Akhtar J, Qureshi R (2004a) Pot study on wheat growth in saline and waterlogged compacted soil I. Grain yield and yield components. Soil Till Res 77:169-177

Saqib M, Akhtar J, Qureshi R (2004b) Pot study on wheat growth in saline and waterlogged compacted soil II. Root growth and leaf ionic relations. Soil Till Res 77:179-187

Sarah P, Zhevelev H (2007) Effect of visitors' pressure on soil and vegetation in several different micro-environments in urban parks in Tel Aviv. Landscape Urban Plan 83:284-293

Scherr SJ, Yadav S (1996) Land degradation in the developing world: Implications for food, agriculture, and the environment to 2020. IFPRI, Food, Agric. and the Environment Discussion Paper 14, Washington D.C., p 36

Schlotzhauer S, Price J (1999) Soil water flow dynamics in a managed cutover peat field, Quebec: field and laboratory investigations. Water Resour Res 35:3675-3683

Schnurr-Putz S, Guggenberger G, Kusell K (2006) Compaction of forest soil by logging machinery favours occurrence of prokaryotes. FEMS Microbiol Ecol 58:503-516

Seladji S, Cosenza P, Tabbagh A, Ranger J, Richard G (2010) The effect of compaction on soil electrical resistivity: a laboratory investigation. Eur J Soil Sci 61:1043-1055

Shestak C, Busse M (2005) Compaction alters physical but not biological indices of soil health. Soil Sci Soc Am J 69:236-246

Shierlaw J, Alston A (1984) Effect of soil compaction on root growth and uptake of phosphorus. Plant Soil 77:15-28

Sigua GC, Coleman SW (2009) Long-term effect of cow congregation zone on soil penetrometer resistance: implications for soils and forage quality. Agron Sustain Dev 29:517-523

Silva AP, Imhoff S, Corsi M (2003) Evaluation of soil compaction in an irrigated short-duration grazing system. Soil Till Res 70:83-90

Silva S, Barros N, Costa L, Leite F (2008) Soil compaction and eucalyptus growth in response to forwarder traffic intensity and load. Rev Bras Cienc Solo 32:921-932

Silveira M, Comerford N, Reddy K, Prenger J, DeBusk W (2010) Influence of military land uses on soil carbon dynamics in forest ecosystems of Georgia, USA. Ecol Indic 10:905-909

Sinnett D, Morgan G, Williams M, Hutchings T (2008) Soil penetration resistance and tree root development. Soil Use Manage 24:273-280

Skiba U, Fowler D, Smith K (1994) Emissions of $\mathrm{NO}$ and $\mathrm{N}_{2} \mathrm{O}$ from soils. Environ Monit Assess 31:153-158

Smith C, Johnston M, Lorentz S (1997) Assessing the compaction susceptibility of South African forestry soils. I. The effect of soil type, water content and applied pressure on uni-axial compaction. Soil Till Res 41:53-73

Smith R, Ellies A, Horn R (2000) Modified Boussinesq's equations for nonuniform tire loading. J Terramechanics 37:207-222

Soane B (1990) The role of organic matter in soil compactibility: a review of some practical aspects. Soil Till Res 16:179-201

Soane B, Pidgeon J (1975) Tillage requirement in relation to soil physical properties. Soil Sci 119:376-384

Soane B, Van Ouwerkerk C (1995) Implications of soil compaction in crop production for the quality of the environment. Soil Till Res 35:5-22

Soane B, Dickson J, Campbell D (1982) Compaction by agricultural vehicles: a review III. Incidence and control of compaction in crop production. Soil Till Res 2:3-36

Söhne W (1958) Fundamentals of pressure distribution and soil compaction under tractor tyres. Agr Eng 39:276-281

Sowa J, Kulak D (2008) Probability of occurrence of soil disturbances during timber harvesting. Croat J For Eng 29:29-39

SSSA (1996) Glossary of soil science terms. Soil Science Society of America, Madison

Tan X, Chang S (2007) Soil compaction and forest litter amendment affect carbon and net nitrogen mineralization in a boreal forest soil. Soil Till Res 93:77-86 
Tan X, Chang S, Kabzems R (2008) Soil compaction and forest floor removal reduced microbial biomass and enzyme activities in a boreal aspen forest soil. Biol Fert Soils 44:471-479

Tardieu F (1994) Growth and functioning of roots and of root systems subjected to soil compaction. Towards a system with multiple signalling? Soil Till Res 30:217-243

Taylor HM (1971) Effects of soil strength on seedling emergence, root growth and crop yield. In: Barnes KK, Carleton WM, Taylor HM, Throckmorton RI, van den Berg GE (eds) Compaction of agricultural soils. American Society of Agricultural Engineers, St. Joseph, pp 292-305

Taylor HM, Ratliff LF (1969) Root elongation rates of cotton and peanuts as a function of soil strength and soil water content. Soil Sci 108:113-119

Taylor H, Roberson G, Parker JR (1966) Soil strength-root penetration relations for medium-to coarse-textured soil materials. Soil Sci 102:18-22

Tworkorski T, Burger J, Smith D (1983) Soil texture and bulk density affect early growth of white oak seedlings. Tree Plant Notes $34: 22-25$

Usowicz B, Lipiec J (2009) Spatial distribution of soil penetration resistance as affected by soil compaction: the fractal approach. Ecol Complex 6:263-271

Van den Berg F, Kubiak R, Benjey W, Majewski M, Yates S, Reeves G, Smelt J, Van der Linden A (1999) Emission of pesticides into the air. Water Air Soil Poll 115:195-218

Van-Camp L, Bujarrabal B, Gentile AR, Jones RJA, Montanarella L, Olazabal C, Selvaradjou SK (2004) Reports of the Technical Working Groups Established under the Thematic Strategy for Soil Protection, EUR 21319 EN/3. Office for Official
Publications of the European Communities, Luxembourg, p 872

Voorhees W, Hendrick J (1977) Our newest natural resource; compaction, good and bad effects on energy needs. Crops Soils 29:11-13

Voorhees W, Farrell D, Larson W (1975) Soil strength and aeration effects on root elongation. Soil Sci Soc Am J 39:948-953

Wakindiki I, Ben-Hur M (2002) Soil mineralogy and texture effects on crust micromorphology, infiltration, and erosion. Soil Sci Soc Am J 66:897-905

Webb R (2002) Recovery of severely compacted soils in the Mojave Desert, California, USA. Arid Land Res Manag 16:291-305

Weert R (1974) Influence of mechanical forest clearing on soil conditions and the resulting effects on root growth. Trop Agr (Trinidad and Tobago) 51:325-331

Williamson J, Neilsen W (2000) The influence of forest site on rate and extent of soil compaction and profile disturbance of skid trails during ground-based harvesting. Can J Forest Res 30:1196-1205

Yao H, Conrad R, Wassmann R, Neue H (1999) Effect of soil characteristics on sequential reduction and methane production in sixteen rice paddy soils from China, the Philippines, and Italy. Biogeochemistry 47:269-295

Yu H, Mitchell J (1998) Analysis of cone resistance: review of methods. J Geotech Geoenviron 124:140-148

Zenner E, Berger A (2008) Influence of skidder traffic and canopy removal intensities on the ground flora in a clearcut-with-reserves northern hardwood stand in Minnesota, USA. Forest Ecol Manag 256:1785-1794

Zenner E, Kabrick J, Jensen R, Peck J, Grabner J (2006) Responses of ground flora to a gradient of harvest intensity in the Missouri Ozarks. Fores 222(1-3):326-334 